\title{
BREAKING THE WAVE. THE CONTESTED LEGITIMATION OF AN ALIEN ORGANIZATIONAL FORM ${ }^{1}$
}

GIUSEPPE DELMESTRI

Department of Business Administration

Bergamo University

Via dei Caniana, 2

24127, Bergamo - Italy

giuseppe.delmestri@unibg.it
FILIPPO CARLO WEZEL

Institute of Management,

Faculty of Economics

University of Lugano

Via Buffi, $13-6900$

Lugano - Switzerland

$\&$

Extramural Fellow of CentER, Tilburg University - The Netherlands wezelf@usi.ch

Forthcoming, Journal of International Business Studies

\footnotetext{
${ }^{1}$ The authors contributed equally. The authors acknowledge their debt of gratitude with Witold Henisz for his editorial work. The manuscript benefited considerably from comments of three anonymous referees. The participants to the EGOS and to the Academy of Management conferences, and to the seminars held at the Alberta School of Business and at the Hong Kong University of Science and Technology provided insightful comments on earlier versions of the manuscript. We also wish to thank Severino Salvemini for his encouragement at the beginning of the study and Michael Woywode for his contribution in the early stages of development of this project.
} 


\section{Biography}

Giuseppe Delmestri (Ph.D. Mannheim University, Germany) is associate professor of organization theory at the department of business administration of Bergamo University (Italy). He previously held an appointment at Bocconi University. He actually focuses on cross-national studies of multiple institutional logics, product categorizations, managerial identities and branding. His work has been recently published in Organization Studies, Journal of Management Studies, International Journal of Human Resource Management, Research in the Sociology of Organizations and Human Relations.

Filippo Carlo Wezel is professor of organization theory at the faculty of economics of University of Lugano (Switzerland) and he is a senior Extramural Fellow of CentER, Tilburg University (the Netherlands). He previously held appointments at Groningen University and at Tilburg University. His research focuses on industry emergence, inter-firm mobility, and identity-based competition. His work has been recently published in Academy of Management Journal, Organization Science, Organization Studies, and Long Range Planning. 


\title{
BREAKING THE WAVE. THE CONTESTED LEGITIMATION OF AN ALIEN ORGANIZATIONAL FORM
}

\begin{abstract}
Organizational forms imbued with values of modernity -- i.e., rationality, efficiency and equity rapidly diffuse around the world. Nonetheless, when sustained by beliefs, norms and regulations contrasting with those prevalent in the receiving country, their adoption may be delayed, and withincountry legitimation may not proceed smoothly. We study the diffusion of multiplex-cinemas -- a form conceived in the US and attuned to the cinema-as-commerce logic -- across Europe, where the cinema-as-art logic prevails. Our findings reveal that the cultural meanings embodied by multiplexes shaped the founding rates of this organizational form in three ways. First, countries with larger normative and regulative distance from the US retarded the adoption of the first multiplex. Second, camouflaged entries, followed by opposition from local interest groups, were observed. Third, the embodiment of global cultural scripts of progress and modernity allowed multiplexes to overcome local opposition. The normative distance of the country from the US amplified the fluctuating dynamics of within-country legitimacy. A new specification of density-dependent legitimation is presented to model the cultural-cognitive legitimacy of rationalized but alien organizational forms.
\end{abstract}




\section{INTRODUCTION}

New organizational forms, policies, and practices, when theorized with reference to the pillars of modernity (i.e., efficiency and progress or equity and justice) easily diffuse among nation states in the world society (Meyer \& Hannan, 1979a; Jepperson \& Meyer, 1991; Meyer et al., 1997; Hwang \& Powell, 2005; Simmons et al., 2006; Drori, 2008). Thanks to theorization -- which allows abstracting the properties of a diffusing entity and specifying the expected outcomes -- cultural categories may arise and gain force (Strang \& Meyer, 1993). Notwithstanding the various instances of global diffusion that generated waves of organizational expansion (Drori et al., 2006; Meyer et al., 1997), recent research has started to investigate the apparent contradiction between the cross-national diffusion of a cultural entity consonant with the beliefs and values of modernity and the manifestation of local legitimacy struggles (Zelner et al., 2009; Weber et al., 2009; Ansari et al., 2010).

The present paper builds on this latter body of research and further investigates the processes of cross-national diffusion and of local legitimation of a rationalized organizational form. ${ }^{2}$ By focusing on local legitimation, institutional theory (Meyer and Rowan, 1977; Meyer et al., 1997) and organization ecology (Hannan \& Freeman, 1977) become our natural benchmarks. Notwithstanding the similarities among these theories, a few differences appear evident (see also Haveman \& David, 2008). Ecologists have primarily focused on the cognitive dimension of local legitimation (Hannan \& Freeman, 1989; Hannan et al., 1995), where cognition is regarded from an individual atomistic standpoint and the social facet of cognition is confined to patterns of local interaction. In this respect, culture-free audience members play a leading role (Hsu \& Hannan, 2005). Conversely, institutional theorists underscored legitimacy as a sociopolitical process (Aldrich \& Fiol, 1994) involving the anchoring to the norms and the regulations prevailing in the importing context (see, e.g., Ansari et al., 2010), and the enactment of global cultural scripts (Meyer et al., 2007).

\footnotetext{
${ }^{2}$ In the present paper we define as a rationalized organizational form, an organizational form theorized with reference to one or all the pillars of modernity - i.e., efficiency and progress or equity and justice. In so doing we build on Drori and her colleagues (2006: 206) who defined rationalization as "the explicit organization of clearly defined social entities and their roles, relationships, and activities around clear and general rules and toward clear and general purposes". Scientization, higher education and the professionalization of management through Business Schools are considered the pillars supporting the global culture of rationalized organizations -- even more so upon the worldwide expansion of the neoliberal ideology.
} 
We aim at contributing to this debate by showing the limits of a culture-free conception of cognition and the relevance of cultural-cognitive, normative and regulative aspects of legitimacy. In particular, we contend that the local legitimacy of an organizational form is not only shaped by the enactment of world standards but also entails a complex interaction between global cultural scripts and local beliefs, norms and values. A detailed understanding of this process requires an investigation of the hindering and supporting mechanisms to the legitimation of an organizational form upon its adoption (see also Drori et al., 2006). The present paper thus contributes to our understanding of the process of local implementation of a globally diffusing practice, an issue scantly explored by world polity research which usually stops once a practice is locally adopted (e.g., Meyer et al., 1977; Paxton et al., 2006) or explores local opposition as either delaying or impeding the adoption of the first instance of a practice (e.g., Hafner-Burton \& Tsutsui, 2005; Weber et al., 2009) - for an exception on the dynamic and contested nature of policy implementation see Zelner and colleagues (2009).

To reach this goal, we study the interaction between global cultural scripts and local beliefs, norms and values with reference to first-time adoption as well as to the attainment of local legitimacy by a rationalized organizational form. The distinction between first time adoption and subsequent local diffusion is instrumental not only to clarify how culture matters in shaping the adoption of such an organizational form, but also to discuss how cultural differences mold its attainment of local legitimacy. In particular, while the first time adoption of a rationalized organizational form is accelerated by its international diffusion, it is delayed by the normative and regulative distance of the focal country from the beliefs, norms and regulations embodied by the form. When considering within country diffusion, we expect cultural-cognitive distance to incentivize camouflaged entries ${ }^{3}$ and, subsequently, opposition from local interest groups. Eventually, reference to the values of progress and modernity may grant the support of relevant audiences and overcoming local opposition. The consequences of cultural differences on the attainment of local cognitive legitimacy are captured through a new specification of density-dependent legitimation. As the mechanisms of local diffusion

\footnotetext{
${ }^{3}$ Camouflage is the method through which an otherwise visible social entity remains indiscernible through dissimulation (see Hargadon and Douglas, 2001; Zuckerman and Kim, 2003). Camouflage differs from "bricolage" which refers to processes of "recombination of old institutional elements" supporting institutional change jointly with translation - i.e., with the addition of new institutional elements (Campbell, 2004: 28).
} 
hinge upon cultural-cognitive differences, we expect them to be reinforced by the normative and regulative distance of the focal country from the US. Indeed, camouflaged entries and opposition should be particularly incentivized in European countries at odds with the norms and regulations embedded in the multiplex form. Conversely, we expect any reference to the values of progress and modernity to be especially relevant in such countries to overcome local opposition. ${ }^{4}$

Qualitative and quantitative evidence is employed to study the diffusion of multiplex cinemas across various European countries during the period 1980-2005. This empirical context suits our research questions because of the clash between the cinema-as-art logic (common in Europe) and the cinema-as-commerce logic embodied by the multiplex form and originated in the Unites States: "nobody ever called it show art; it's show business" said the famous American producer Samuel Goldwyn (quoted in Castellina, 2010: 4; see also Caves, 2000). Indeed, the multiplex form embodies the logics of professionalization and managerialization, central to the cultural construction of world society as opposed to family and state-bureaucratic logics (Meyer et al., 2007) and the fit between this rationalized organizational form and world societal values is pivotal to its global diffusion (Meyer et al., 1997). The paper will proceed as follows. In the next section we sketch the history of the multiplex form. Then, we introduce our theoretical framework and two sets of hypotheses concerning (i) the hazard of founding of the first multiplex cinema in each of the countries of our sample, and (ii) the subsequent dynamics of local legitimation within each country. In the last section, we discuss how our results contribute to organization ecology (Carroll \& Hannan, 2000; Hannan et al., 2007) and new institutionalism (Meyer \& Rowan, 1977; Meyer et al., 1997).

\section{MULTIPLEX CINEMAS: THEORIZATION AND DIFFUSION ACROSS EUROPE}

The birth of the multiplex as a new organizational form is a North American success story. Stanley Durwood, the founder of the US-based AMC, is known as the entrepreneur that revolutionized the industry (La Franco, 1996; Klady, 1999; Delon, 2000). Durwood started applying the insights of

\footnotetext{
${ }^{4}$ The last two decades of the Twentieth century represented the period of maximum expansion of neoliberal ideology (Simmons et al., 2006) and the global cultural scripts concerning the effectiveness of managerialized organizations rapidly diffused.
} 
management science to modernize the movie-theatre industry (La Franco, 1996). His path-breaking innovation moved beyond the increase of the number of screens to divide fixed personnel costs and the offer of variety to the public: he conceived multiplexes as special purpose buildings within shopping malls, featuring state-of-the-art technology in terms of viewing, sitting, and ancillary services. Durwood's AMC broke new ground in European cinema as well due to the opening of the first American multiplex in a foreign country -- i.e., the AMC complex in Milton Keynes in 1985 (Maunder, 1996; McDonald, 2006). In a few years span, the European movie-theater industry was transformed by the diffusion of the multiplex form, which brought forward organizational, financial and marketing innovations (Kim \& Mauborgne, 1997). According to Chaudhuri (2005: 4):

"Since 1986, the US majors have been fostering the growth of multiplexes internationally as part of their blockbuster release strategy. Apart from Western Europe (which has the largest number of multiplexes outside the USA), multiplexes have gradually been built in Eastern Europe, and there has been an 'explosion' of multiplex construction in part of Asiaincluding Japan, Thailand and India."

But what exactly is a multiplex? In the North American context, a precise theorization emerged only at the end of the 1970s. Multiplex were defined as purpose-built, up to date theaters with at least 6-8 screens positioned within a shopping mall and offering ancillary services (e.g., fast food and additional entertainment). The opening of Nat Taylor's Toronto's 18-screen Guinness Book of World Records theatre in 1979 contributed to seal this theorization as the dominant one. In Europe, the Cinema Expo International trade fair and MEDIA Salles, set up by the cinema owners' associations of 13 Western European countries, were established in 1992 - jointly with the Confédération Internationale des Cinémas d'Art-et-d'Essai Européens (CICAE). MEDIA Salles, as one of its first acts, commissioned a report -- "White Book of the European Exhibition Industry", published in 1994 that describes the multiplex form as follows:

"There is a large degree of inconsistency in the way that multiplexes are defined in different studies and in different countries. Some believe that the key factor is the number of screens, but many others also believe that additional features must be present (e.g. parking facilities) for a multi-screen complex to be defined as a multiplex. ... Notwithstanding the difficulty of separating screens that are built as additions from those obtained by partitioning of the original one, in the analysis carried out in this paper, a multiplex is defined as a purpose built multi-screen facility with eight or more screens."

MEDIA Salles proposed eight screens to become the official threshold for defining a multiplex cinema. However, the MEDIA Salles definition turned out to be fuzzier than the North 
American one because it did not differentiate among restructured movie-theaters (i.e., multiscreen theaters), and purpose-built multiplexes. When the multiplex boom started in the 1980s (in the UK, and in Sweden and Belgium), in Germany and France multiscreen theaters were still conceived from the subdivision of pre-existing auditoria (Demil \& Leca 2003; Maunder 1996). Conversely, French multiscreen theaters, thanks to generous public subsidies aimed at defending movie-theaters as a fundamental part of national culture, were restructured both architecturally and technically. Only at the end of the 1990s, through the specification of the codes for the sub-forms megaplex (at least 16 screens) and miniplex (purpose-built theater multiscreen with less than 8 screens), a theorization closer to the North American counterpart, was eventually conceived.

Although multi-screens and multiplexes share common features (e.g., economies of scale through the sharing of ticket-counters' personnel and peripheral services, such as for drinks and food, and the offer of a wide variety of films), multiplexes represent a substantive innovation, which aimed at offering a new experience to the visitor (Blin, 1999). On the contrary, multi-screens represent an incremental reaction to the slump in ticket sales due to the proliferation of TV and VCR in the households in the Seventies/Eighties (Kim \& Mauborgne, 1997). Furthermore, multiplexes initially located in city suburbs, while incumbent cinemas in city centers (Delmestri, 1993; McDonald, 2006, 2010). Such salient features of multiplexes explain why founding and operating them requires the integration of new knowledge, and the actors carrying this knowledge were traceable in the real estate or the large-scale retail industry (Blin, 1999). By requiring the employment of rationalized marketing and financial techniques, planning, and delegation of responsibility to professionalized and empowered site managers, multiplexes embody the global values and beliefs of efficiency and progress and, therefore, of modernity (Meyer et al., 2007).

Most industry commentators and cinema operators place the birth of multiplex cinemas in Europe to 1985 in Great Britain by AMC (see above), but before the first British multiplex was built, three had been founded in Sweden (1980 and 1984) and in Belgium (1982). Of the 979 European multiplex-establishments founded up until 2005, only eleven had closed down. Of the 968 multiplexes operating in Europe in the year 2005, 631 (65\%) belonged to chains with at least four establishments 
(calculations from our data). Figure 1 displays the evolution of the multiplex population by aggregating the figures concerning 29 European countries (see methods section). ${ }^{5}$ Figure 2 illustrates the number of entries in six representative countries included in our sample.

-- insert Figure 1 and 2 about here --

The diffusion of multiplexes in Europe, did not take place smoothly though. Indeed, the cultural template of multiplexes is at odds with the cultural beliefs and practices of Europeans. First, in Europe cinema is conceived more as an art than a business. In most European countries feature films receive public subsidies, under a welfare idea of art (Potts \& Cunningham 2008). The US-multiplexcinema comes as a bundle of cultural products, structures and stylistic elements, as a genre structured around consumerist and managerial logics (Friedson 2001; Thornton, 2004), i.e. close to shopping malls, featuring prevalently blockbusters and ancillary services related to entertainment and food. Compared to a free-standing movie theatre, the "multiplex movie building cannot really be called a theatre. It is just another business, with no special decor or architectural character. It is a device designed to deliver a commodity effortlessly" (Kupfer, 1990: 325). Second, a multiplex is usually positioned in city-suburbs and reached through private transportation. However, European cities revolve around historical city centres, and promoting the use of private cars runs against deep-seated green convictions. Last, as the Vice President of UNIC, complained at the Cinema Expo International (CEI) 1997 in Amsterdam, most of incumbent cinemas were owned by families that suffered from the "monopolistic practices applied by multiplex-chain operators, such as the misuse of economic power in the supply of film and the acceptance of high initial capital losses" (field notes).

\section{THEORETICAL BACKGROUND}

Organizational ecologists and new institutionalists converge in studying the legitimacy of organizational forms and in defining them as taken-for-granted social entities (Hannan \& Freeman, 1977; DiMaggio \& Powell, 1983; see Haveman \& David, 2008). The key difference between these

\footnotetext{
${ }^{5}$ In order of adoption, the countries are: Sweden, Belgium, UK, Norway, Spain, Ireland, Germany, Portugal, Malta, Austria, Switzerland, France, Denmark, Netherlands, Czech Republic, Luxemburg, Hungary, Italy, Greece, Finland, Poland, Slovakia, Romania, Slovenia, Estonia, Lithuania, Russia, Latvia, Croatia, and Bulgaria.
} 
perspectives lies in the approach to legitimation: while ecologists investigate abstract models of population evolution and focus on the achievement of cognitive legitimacy (Hannan \& Freeman, 1989; Hannan et al., 1995; see Haveman \& David, 2008), institutional theorists underscore the anchoring of organizational forms to wider institutional fields and focus on the beliefs, norms, and regulations that sustain their existence (i.e., on the cultural-cognitive, normative and regulative dimensions of legitimacy - see Scott, 2001; Ruef \& Scott, 1998). Even the cognitive dimension of legitimacy appears conceived differently across the two perspectives. While for ecologists cognition is invoked primarily with reference to informational-cognitive processes (Hsu \& Hannan, 2005; Dequech, 2003), for institutional theorists cognition is anchored to the cultural logics (i.e., whether at the field-, at the national- or at the global-level, see, respectively, Ansari et al., 2010; Fiss \& Zajac, 2004; Meyer et al., 1997), and to the norms and regulations prevailing in the importing context.

In the present paper, we aim at discussing the limits of a conception of organizational forms as culture-free entities and contend that their international diffusion and their achievement of withincountry legitimacy represents a cognitive, cultural and political process (Czarniawska \& Joerges, 1996; Djelic 1998; Mazza et al., 2005; Djelic \& Sahlin-Andersson 2006; Geppert et al., 2006; Delmestri \& Walgenbach, 2009). When adopting a cultural-cognitive point of view, organizational forms assume meaning and substance with reference to the cultural construction of the world polity (Meyer et al., 2007; Wotipka \& Ramirez, 2008) and to local beliefs, norms and values (Friedland \& Alford, 1991; Ansari et al., 2010). In the European diffusion of the multiplex, we contend that such local forces interacted with global cultural scripts form as follows: (i) the speed of adoption of the first multiplex was shaped by the normative and regulative distance of the country from the beliefs, norms and values that this form embodies; (ii) within country legitimation was molded by the manifestation of camouflage and of opposition by local interest groups and that their successful local spread was sustained by the reference to cultural values of progress and modernity; last, (iii) we expect the consequences of cultural differences on the local attainment of cognitive legitimacy to be moderated by the normative and regulative distance of the focal country from the US. 
Across-Countries Diffusion: Cognitive, Normative and Regulative Antecedents

Organizational ecologists and new institutionalists assume that the more an entity is enacted, the more it becomes taken for granted (and vice versa). Nonetheless, the latter group of scholars moves beyond informational-cognitive processes and stresses the rationale associated with the diffusing social entity as providing value and meanings to it. According to this view, the multiplex organizational form may be locally adopted not only because successfully diffused all over Europe ${ }^{6}$, but also because rationalized around culturally legitimate values and goals - e.g., the professionalized dissemination of cultural products beyond the possibilities of state-protected family establishments. Indeed, while the increasing diffusion of multiplexes in Europe facilitates the sensemaking of this organizational form, emulation may be greatly facilitated by reference to the cultural-cognitive scripts of modernity (Meyer et al., 2007). Processes of emulation have been demonstrated across a wide variety of empirical settings (e.g., Frank et al., 2000; Simmons \& Elkins, 2004; Henisz et al., 2005; Weber et al., 2009).

The emergence of a multiplex cinema in the focal country should be accelerated by the institutionalization of this organizational form at the European level. Indeed, through the establishment of MEDIA Salles and trade conferences, the multiplex form became framed as aligned with values of modernity and efficiency, stimulating local emulation -- see e.g., Hellpointer (2004) and Perotti (2004) Building on these arguments, the cognitive pressures stemming from the theorization and the diffusion of multiplexes in Europe should increase the chances of local adoption - above and beyond network position and power (see Koo \& Ramirez, 2009). Thus, the hazard of founding of the first multiplex in the focal country should increase with the European diffusion of this form. We employ European density (i.e., the number of multiplexes or their density) as a proxy of cultural-cognitive legitimacy:

\section{Hypothesis 1: Increasing density of multiplex cinemas in Europe increases the hazard of}

founding of the first multiplex cinema within the focal European country.

\footnotetext{
${ }^{6}$ Organization ecologists have developed the concept of supranational density-dependent legitimation and analyzed its effect on national level entry rates. However they never hypothesized about its influence on the chances of founding the first instance of the form in the focal country. Nonetheless, the narrative is that the cognitive legitimacy of an organizational form overcomes national boundaries, as its underlying concept diffuses more widely than the material and human resources necessary to support the form (Hannan and Carroll 1992). Hannan and his colleagues (1995) corroborated this view by analyzing the entry rates of automobile manufacturers in various countries, ultimately finding that national spread was primarily driven by the European density of automobile producers, while competition only by national density (see also Wezel and Lomi, 2003).
} 
Above and beyond cognition, a country's normative and regulative characteristics should affect the rates of adoption of a rationalized organizational form (for a similar argument see, e.g., Weber et al., 2009). Cultural and institutional similarity in particular should speed up its adoption (see Strang \& Meyer, 1993). Indeed, trait-based imitation is facilitated in presence of similarity with the importing context (Henisz \& Delios, 2001; Fombrun \& Shanley, 1990, Haveman, 1993, Strang \& Tuma, 1993, Haveman \& Rao, 1997). Conversely, distance along norms, values and regulations is expected to retard the adoption of the first instance of the organizational form by the focal country.

The qualitative information collected suggests that the normative and regulative distance of the adopting country from the US-norms and rules carried by the multiplex form especially mattered -i.e., consumerism, managerialism and professionalization (Friedland \& Alford 1991; Friedson 2001). Notice that while regulative distance (Kostova, 1999; Xu \& Shenkar, 2002; Xu, Pan \& Beamish, 2004) captures the regulative environment - e.g., laws, rules and relationship among citizens with legitimate power holders (Weber, 1978/1921) -, normative distance concerns national norms and values $^{7}$ (e.g., Ronen \& Shenkar, 1985; Kogut \& Singh, 1988). Thus, the more distant the focal country is from US values and norms, the lower the hazard of adoption of the new form. The opposite holds true when considering the liberalism of the focal country (Whitley, 1994; Ruef \& Scott, 1998; Ingram \& Rao, 2004; Drori, et al., 2006). Therefore, we propose the following hypotheses:

Hypothesis 2: The larger the normative distance between the focal European country and the USA, the lower the hazard of adoption of the first multiplex cinema will be.

Hypothesis 3: The larger the institutional and economic liberalism of focal European country, the higher the hazard of adoption of the first multiplex cinema will be.

\footnotetext{
${ }^{7}$ Institutional theorists tend to use the adjective "cultural" in a broader sense than cross-cultural psychologists to take into account both the cognitive (meanings) and the normative (norms and values) dimensions of institutions. Thus, we call normative distance the construct grounded in cross-cultural psychology developed by Kogut and Singh (1988) named by these authors "cultural distance", and grounded in cross-cultural psychology, which overlaps with Scott's (2001) normative pillar. Our regulative distance clearly covers Scott's regulative pillar.
} 
Within-Country Density-Dependent Legitimation: Beyond Sheer Cognition

World polity research oftentimes stops once the focal event (e.g., the adoption of a public policy) occurs, implicitly assuming that the local implementation proceeds smoothly (see Zelner et al., 2009). Density-dependence theory (Hannan \& Freeman, 1989) moves beyond this limitation with respect to the cognitive legitimacy of an organizational form. Under the premise that a new organizational form acquires cognitive legitimacy displaying a socially recognized template (Hannan \& Freeman, 1989; Hannan et al., 2007), density increases improve its social recognition. Even when considering the limited multi-country studies (e.g., Hannan et al., 1995), local diffusion appears unhindered and density-dependent legitimation is argued to influence a country's founding rates either in a linear or log-linear fashion (see Hannan \& Freeman, 1989). Any initial resistance to the diffusion of a new organizational form is a matter of absence of a reference category that allows audience members making sense of the new social entity (Dobrev et al., 2006; Hsu \& Hannan, 2005).

Nonetheless, when a rationalized form is imported - very much like a public policy (see Zelner et al., 2009; Weber et al., 2009) -- various problems may hinder its road to local legitimacy. As Meyer and colleagues recently argued (2006: 260,261) the local enactment of global scripts requires their "modification ... in light of variations in local conditions", and "often there is contestation over local interpretation". Indeed, according to Ansari and colleagues (2010), the attainment of local legitimacy is not only a matter of sheer prevalence of an organizational form, but also of fit with the beliefs, norms and regulations of the importing context. While reference to global cultural scripts acts as a supporting mechanism to the legitimacy of the form, local cognition is filtered by the degree of cultural fit between the adopting country and the values and beliefs embodied by the diffusing form.

Evidence from various European countries suggests that the diffusion of multiplexes encountered the opposition of local interest groups. In Hungary, for instance, the prominent director Béla Tarr refused his new film to be shown in a multiplex, chosen for the 2001 Film Week, and succeeded in moving the show to the traditional Atrium cinema (Cunningham, 2004: 156). In France, it was Pierre Bourdieu who offered support to the contra-multiplexes proponents referring to this organizational form as an evil example of globalization and Neoliberalism (Bourdieu, 2001), while the 
anthropologist Marc Augé referred to the multiplex as a "non-place" (quoted by Bianchini, 2004). Similarly, in the Italian region of Tuscany, multiplex foundings were stopped until 2002 by local regulations. In Florence, the opening of a multiplex became the object of fierce electoral contention among left and right wing parties leveraging on opposite frames such as McDonaldization and economic freedom (Bogani, 2008; L'altracittà, 2009). Even in the UK, the Friends of the Earth Trust, published on-line the article "Invasion of the multiplex monsters - Cinema boom threatens traffic and pollution chaos" (6 June 1996), reporting a campaign against multiplexes on the following bases: "Up to 24,000 people die prematurely every year because of air pollution. That's the equivalent of fourteen Titanics. Action to cut car use is essential if these deaths are to be stopped".

In France, the opposition started in 1995 (Kim \& Mauborgne, 1997), and even more forcefully in 1999. In 1995, a multiplex (i.e., 4085 places and 14 screens) opened in Saint-Julien-lès-Metz, an independent municipality in the periphery of Mets (BIPE Conseil, 1994). As a consequence, movietheatres in Metz had to close down, causing the first major conflict between central and peripheral municipalities reported nationwide (Blin, 1999). A year later, the movement of protest among city centre shops owners and citizens was framed as "Friends of independent movie theaters" and made a petition to courts "against the multiplexes that menace" (Bedarida, 1996; Monin, 1996). In 1999, in Conflans-Sainte-Honorine, near Paris, twelve different associations embarked in street protests and petitions against the planned multiplex and for "un cinéma à taille humaine" (a movie-theater on a human scale) (Chantry, 1999). A few years earlier, the Government issued a decree (converted in law in 1998) according to which the establishment of multiplexes larger than 1300 seats required local endorsement. In parliamentary debates leading to the new regulation, multiplexes were labelled as the "aircraft carrier" of American lifestyle (Delon, 2000), and local cultural élites saw them as "a fifth column for American movies" (Tagliabue, 2000). In 1999, this regulation was revised down to 300 seats, under the concern that cinemas located faraway from city centres could modify citizens' habits, and, especially, tarnish the cultural activities offered therein (Delon, 2000). Broadly speaking, multiplexes were perceived as promoting "spatial commodification, replacing smaller, local cinemas with large multi-screen sheds" and cities are "already struggling to resist a(nother) McDonald's, 
Walmart, mall or multiplex, which are generally developed at the cost of existing, independent or at least more widely distributed outlets and town centres" (Evans, 2003: 422, 418).

Similarly, in Italy, several projects were stopped by petitions to courts, particularly in the years 1997 and 1998. The association of cinema owners (ANEC) mobilized cultural elites in depicting multiplexes as a threat to Italian artistic movies and as Trojan horses for American values and lifestyle (Rooney, 1999). The opponents to the diffusion of multiplexes criticize the employment of a consumeristic logic within the cultural domain of cinema-theatres, so far organized around the family and welfare logics (Perotti, 2004). In Germany, in 1991, the national association of movie-theatre owners (HDV), framed the six existing multiplexes as the "Invasion der Multiplexe" and counterframed their commercial image by stating: "Film ist Ware und Kulturgut" (film is both a product and a cultural good). Schmitt (1992: 39) reports of "conflicts" arising after the first establishments, when "a broad alliance" of municipalities and cinema owners threatened petitions to courts to stop such airpolluting "commercial entertainment shops" intended to "destroy existing cultural realities". Such protests led municipalities as from the mid-Nineties to ask multiplex-operators to locate their projects closer to city centres and to increase their architectural quality (Hellpointer, 2004).

Interestingly, the contestation of local interest groups may need time to take off because entrepreneurs may act strategically and camouflage the identity of their businesses (see Ingram et al., 2010). Camouflaging is a well-known strategy to prevent local opposition (Hargadon \& Douglas, 2001; Zuckerman \& Kim 2003: 57) and, at a more aggregate level, delays the emergence of the category that underlies the new organizational form. New instances tend to be sorted into pre-existing categories (Weick 1995: 2, 12) - even more so in presence of camouflage - and enough consistent examples are needed to crystallize the existence of a new organizational category (McKendrick et al., 2003). Various instances of camouflage are traceable in the diffusion of multiplexes in Europe. The first multiplex in Italy was created by bundling together licenses of red-light movie theatres and adopted the traditional label "multisala". Indeed, Perotti (2004), content-analyzed discourse on multiplexes in Italian trade journals and leading newspapers, and found that it took several years for the words "multisala" (i.e., multiscreen theatre) and "multiplex" to be used in a semantically distinct 
way, while in the first few years the meaning of the two words was overlapping. Moreover, consider that the first French multiplexes were limited in size to eight screens - i.e., a size not different from that of multiscreen theatres; to attract less attention, the first establishments occurred in areas far away from cities in the UK; the initial establishments of German operators, designed following architectural templates of the movie palaces of the 30ies, were closer to city centres, not adjacent to a shopping mall, and had only eight screens; similarly, the first Hungarian multiplex was built on the site of the historic Corvina cinema, and "the renovators have restored the original façade and the largest auditorium to their former glory" (Cunningham, 2004: 152). Multiscreen theatres, invented in Germany and France few years after the first instances of multiplexes in the United States, by combining elements of modernity (e.g., scale economies and managerialization) and traditional characteristics of monoscreens (i.e., location in city centers; loyalty to the European model of cinemas), turned out to be a camouflaged translation of the multiplex form.

Once an organizational category emerges, further attempts at camouflaging become unfeasible and the opposition of local interest groups gets ignited. Because of local opposition, entry decisions are postponed (see also Ingram et al., 2010). Nonetheless, the actions of the proponents of a rationalized form are empowered by reliance on global cultural principles that clarify the nature and the purposes of the organizational form. Modernity and progress are among the most effective and privileged global norms (Drori, 2008). The cultural principles of modernity and progress are ideologically inscribed to a rationalized idea of organization that encompasses professional management by means of rational quantifications, accounting and use of standardized management practices (see Meyer et al, 2006). Multiplexes embodied all of these characteristics - see the section on industry background. Eventually, reference to global cultural scripts of progress and modernity allowed multiplexes to overcome the opposition of local interest groups (Meyer et al., 1997; Meyer, 2008). As one of the informants of Tagliabue (2000) described it, breaking the opposition to the diffusion of multiplexes in France became an inevitable corollary of modernity: "Can we always stop the Concorde from flying?" Similarly, the Italian Culture Minister in 1998 liberalized the 
establishment of multiplex cinemas with the explicit aim to rejuvenate the national industry and to inject standards of modernity, professionalism and efficiency into the sector (field notes).

Building on this logic, we claim that the linear road to within-country legitimacy of a rationalized organizational form takes on a different shape when the cognition of local audience members - e.g., consumers, regulators or funding agencies - is filtered by a cultural model at odds with the one represented by this organizational form. Entrepreneurs will recur to camouflage, and opposition from local interest groups will slow down its diffusion. However, the embodiment of cultural-cognitive scripts of modernity acts as a supporting mechanism to overcome local contestation. Therefore, we expect multiplex founding rates to exhibit an initial increase (thanks to camouflage), followed by a slow down (due to opposition) and, eventually, by a further increase (due to the full enactment of the global cultural scripts of modernity embodied by the form).

Hypothesis 4: The number of multiplex cinemas in the focal European country is positively associated with founding rates (camouflage), up to a level after which this relationship turns negative (opposition), and eventually becomes positive again (full legitimacy).

Cultural differences matter for within-country legitimacy also because normative and regulative distance may be argued to moderate the effects postulated by $\mathrm{H} 4$. Stronger fears of normative opposition should reinforce the tendency to recur to camouflage. Indeed, in the late 1990s when American chains targeted new and normatively more distant countries, they heavily recurred to camouflage. First, they dedicated (or at least pretending to dedicate) one of the screens to art house cinema, pushing forward an illusionary logic of choice: "multiplexes are capable of expanding the range of films on offer, [but, as the] film market continues to be dominated by US-produced films distributed by the major Hollywood studios, multiplexes deliver only the 'myth' or 'illusion' of choice" (McDonald, 2010, p. 267, referring to Stuart 2000: 54, 57). Second, US chains tried to locate multiplexes physically and symbolically distant from shopping malls. Nonetheless, the more this strategy was followed, the more it became apparent that "[s]uch stylistic mélange is usually no more than a facile camouflage for the standardized containers of modernism" (Kupfer, 1990: 325). Opposition emerged as particularly strong among normatively distant countries. The most effective 
lever to overcome such opposition turned out to be the reference to the values of progress and modernity. Modern features, indeed, should be more evident in a traditional cultural environment than in an equally modern one (e.g., try to imagine a multiplex located in an Italian art city as compared to one positioned in London). As for instance an Italian independent mono-screen owner put it, "while the multiplex form inevitably takes something away from traditional cinemas, in the long run brings dynamism and innovation to the industry as a whole" (Rita Stella, Giornale dello Spettacolo, October 8,1999 , our translation). Building on these arguments, we expect the fluctuating pattern of within country diffusion described by Hypothesis 4 to be more pronounced among normatively distant countries. Conversely, countries more familiar with the norms that the new form embodies should be less exposed to camouflage and to contestation and go through a smoother process of densitydependent legitimation. An opposite reasoning should hold true when considering the distance of the focal country from a liberal market economy. Thus, we propose the following hypotheses:

Hypothesis 4a: The fluctuating relationship between multiplex cinemas density and founding rates is amplified by the normative distance of the focal European country from the US.

Hypothesis 4b: The fluctuating relationship between multiplex cinemas density and founding rates is reduced by the institutional and economic liberalism of focal European country.

\section{DATA}

The data set employed for the test of the hypotheses has been developed by relying on the yearly information published since 1991 by MEDIA Salles concerning all European Union countries. A few countries have been excluded from our sample in the testing $\mathrm{H} 4$ and moderators either because only one multiplex was present, or because not even one was founded during our time window. As most of the countries excluded in the second set of analyses involved culturally distant nations (several of which Eastern Europeans), these exclusions should not bias - if not conservatively -- the results obtained concerning within country legitimation. Table 1 reports the different sources for the countries where multiplexes appeared before 1991.

-- insert Table 1 about here -- 
Because the only requirement for identifying a multiplex in the MEDIA Salles data set is the number of screens, at least eight, we double-checked the data to delete those attributions inconsistent with our definition. Such a procedure turned out to be especially appropriate in the case of Germany and France. In France, for instance, we purge 31 establishments in 1992, because consistent information from different sources recorded the birth of the first two multiplexes in 1993 (Blin, 1999; Delon, 2000). Data collection and interpretation of the findings was facilitated by experience matured by one of the authors in the study of the European theatrical industry since 1992.

Variables

Two different dependent variables were needed to test our hypotheses. The first one measures whether in a given year the focal country had witnessed the opening of the first multiplex cinema. Once the event occurred, the country is dropped from the risk set. We employ this variable to test Hypotheses 13. The second dependent variable counts the number of multiplexes yearly founded in the focal country and is used to test the hypotheses concerning founding rates ( $\mathrm{H} 4$ and $\mathrm{H} 4 \mathrm{a} / \mathrm{b}$ ).

As for the key independent variables, we employed the (logged) number of multiplex cinemas active all over Europe to test Hypothesis 1 (European Density). We measure Normative distance (Hypothesis 2) of the focal country from the US following established practice in cross-national studies (see Barkema et al., 1996; Delios \& Henisz, 2003) by starting from the measure developed by Ronen and Shenkar (1985) that clustered the countries included in our sample into six cultural blocks, i.e., Anglo, Germanic, Latin European, Eastern European, Nordic cluster and Near Eastern (see Ronen \& Shenkar 2008; Peng et al., 2000; Peng et al., 2006). Further refinements of the measure led to rank the clusters and to develop an ordinal measure of distance. The nearest cultural block to the US was scored one, the next most proximate two, and so forth. We employed such ordinal measure in our analyses. While cruder than the Kogut and Singh (1988) index, "this measure does not implicitly assume that the four factors identified in Hofstede (1980) are the 'true and only' factors capturing 
national culture, nor does it assume linearity, additivity, and normal distributions of the scores on these factors" (Barkema et al., 1996: 157; and see also Shenkar, 2001). ${ }^{8}$

To capture the regulative distance of the focal country, we focused on the liberalism of the institutional and economic regime of each country, employing a measure originally developed by the Fraser Institute, a non-profit research organization, which collects the country-by-country data through 71 cooperation partner institutions. The data can be obtained from the website www.freetheworld.com (Gwartney \& Lawson, 2006). The index includes information on national regulation, freedom of international trade, access to finances, legal structure, security of property rights, size and effectiveness of government, expenditures and taxes. The measure is informative about the distance of the focal country from the ideal of a liberal market regime. Thus, the coding of this variable was reversed to test the hypothesis. Moreover as the measure is reported on a five year basis for the period included between 1970 and 2000 and after 2000 yearly. A linear interpolation was employed to impute the missing data. This measure (Economic Freedom) is meant to test Hypothesis $3 .{ }^{9}$

Our second set of hypotheses challenges the linear and unhindered pattern of local legitimacy depicted by density-dependent legitimation. We proxied the cognitive legitimation of the multiplex form with the number of establishments operating within each country (see Hannan \& Freeman, 1989). However, to show the limits of a culture-free conception of cognition we propose a new specification of density-dependent legitimation able to capture the hindering and the supporting mechanisms described in the theory section. To reach this goal, we created a measure of the density of the multiplex cinemas in terms of the number of establishments that existed at time $t$ in a particular country $i$ (National Density). Quadratic (National Density ${ }^{2}$ ) and cubic (National Density $\left.{ }^{3}\right)$ terms were created to test Hypothesis 4. The polynomial specification is meant to capture the outcome of the three

\footnotetext{
${ }^{8}$ An alternative measure was constructed as well, building on the work of Hofstede (1984). In particular, to proxy the cultural distance between the United States and each European country, we followed the procedure outlined by Kogut and Singh (1988). The findings obtained when employing this variable in the testing of H3 turned out to be qualitatively similar to those reported in the results section.

${ }^{9}$ The robustness of our findings was proven by employing a different proxy of economic freedom. Economic liberalism was measured also as a distance of each country from the US freedom score released by the Heritage foundation - see http://www.heritage.org/Index/Ranking.aspx. The results obtained when employing this measure in the adoption rates analyses turned out to be consistent with those reported here - i.e., increasing distance from the US significantly slowed down the adoption of the first multiplex cinema. As for the founding rates, Hypothesis $4 \mathrm{~b}$ appears even supported when recurring to this alternative index - see results section.
} 
mechanisms postulated. The variables measuring the Normative Distance and the Economic Freedom of the focal country are interacted with the polynomial specification of density to test H4a and H4b. The variables have been mean-centered before computing the interactions. ${ }^{10}$

Several control variables have been added to our models to rule out alternative explanations. Concerning the first-entry analyses, we counted the number of years elapsed since the first appearance of a multiplex in Sweden (European tenure - see the models and methods section for more information). We mapped the macro economic climate of each country by computing the GDP per capita. To do so, we first obtained data concerning the yearly number of inhabitants within each country. Then, the annual figure of the growth of the domestic product (in millions of Euro) for each country and each year was gathered. The data were provided by EUROSTAT (statistical office of the European Union) and, for some Eastern European countries, by national statistical offices. By dividing this measure by the number of inhabitants of each country, we obtained a time-varying proxy of the GDP per capita. Moreover, as Eastern European countries were delayed in adopting the multiplex form before 1990, we created a dummy variable labelled Eastern block. Last, greater integration into the capitalist system and in the international economic and political networks may alter the perception of the new form (see e.g., Weber et al., 2009). Thus we employed van Rossem's (1996) measure to control for a country's overall position in the world system in 1993 - Country's Standing in the World System. We preferred this variable to the one measuring the total exports of the US into the focal country due to missing data (Gleditsch, 2002).

To avoid mistaken attributions of the effects of environmental shifts on entry rates to changes in density (Carroll \& Hannan, 2000), we included three period effects. The first period is defined between 1980 and 1989. This period is marked by the first entrepreneurial efforts in Sweden, Belgium, Norway and UK, which, with the exception of the UK and Belgium, remained almost unnoticed in the rest of Europe. In 1989, the Berlin Wall came down. Following this event the Eastern European

\footnotetext{
${ }^{10}$ Mean centering allows accomplishing two goals: it is strongly recommended in case of polynomial equations as it alleviates the problems of extreme collinearity (Cohen et al., 2003: 204); and by mean-centering the main effects become more meaningful because they characterize the overall relation better. Consider also that meancentering does not hurt either: research shows that the models "are mathematically equivalent and the results for the uncentered case can be obtained from the mean-centered model" (Echambadi and Hess, 2007: 443).
} 
countries started to get integrated into the Western economic system. American ideologies and ideas should have gained in legitimation via this event and created market opportunities all over Europe. The second period concerns the time span between 1990 and 1999. We chose the year 1999 as the ending date for the second period because in this year the Euro, the new currency for eleven Member States of the EU was introduced and became the currency for financial markets, including foreign exchange, share and bond markets. In 2000 the new EU Treaty of Nice was signed with the aim to facilitate the enlargement of the EU into Central Europe. This event pushed the economical and political integration of the EU, and provided additional support to liberal ideas. The third period covers the years 2000-2005 -i.e., the last year of our study. ${ }^{11}$ The (log of) the Number of Monoscreen Cinemas in each country was added to proxy the availability of resources of the focal market. The data were obtained from Media Salles (as from 1990) and from the sources mentioned in Table 1.

To improve the comparability of our models to existing research we also added the European Density of multiplexes (in logs) to the founding rates analysis - after subtracting the density of multiplexes in the focal country. To control for the economic climate of the focal country, the GDP per capita and the Country's Standing in the World System variable (see above) were inserted in the models. Table 2A and $2 \mathrm{~B}$ presents the descriptive statistics and correlations among the variables.

-- insert Table 2A and 2B about here --

Models and Methods

We explore the differential velocity of adoption of the first multiplex across the EU countries included in our sample by resorting to event history analysis (a method advocated for cross-national studies e.g., by Meyer \& Hannan, 1979a: 12-13). In our dataset, each country is at risk as from 1980 (the first EU adoption of a multiplex cinema, in Sweden) and the years elapsed until the first multiplex was founded. Different time functions and different covariates can be used to model the hazard rate of each

\footnotetext{
${ }^{11}$ A further robustness check was run by employing year fixed effects rather than period effects. Two reasons led us, however, to prefer period effects. First, by employing year fixed effects the models faced problems of convergence. The results obtained however turned out to be qualitatively similar to those presented here. Second, provided the relatively limited number of observations (i.e., 487) and countries (20), the addition of 26 further variables to the model would be too costly in terms of degrees of freedom. In further analyses not reported in the paper we also controlled for calendar time (i.e., industry age). The results obtained from this procedure proved to be qualitatively similar to those presented in Table 4 .
} 
country. We model the rate at which the first founding of a multiplex occurs at a particular time, $t$,

conditional upon the values of the observed covariates and upon the event not having occurred prior to time $t$. A log-linear function is used to relate the observed covariates, $X(t)$, to the hazard rate. Adopting the logarithm represents a convenient solution to ensure non-negative hazard rates (Allison \& Waterman, 2002). To allow the baseline hazard to vary in an unrestricted fashion, a piecewise formulation was employed. ${ }^{12}$ We modeled the hazard rate $(r)$ for the country $i$, as a function of period effects $(a)$, a vector of country-specific characteristics and European-level controls $(X)$. That is,

$$
r_{i}(u)=\mu_{j}(a) \exp \left(X_{i a}{ }^{\prime} \alpha\right)
$$

In the second set of analyses we wish to test the hypotheses concerning the diffusion of multiplex cinemas in each European country included in our sample - i.e. $\mathrm{H} 4$ and $\mathrm{H} 4 \mathrm{a} / \mathrm{H} 4 \mathrm{~b}$. The Poisson regression model represents a common solution for studying dependent variables such as that counting the number of multiplex entries that takes only integer values. The entry of multiplexes thus may be conceived as the realization of a Poisson distribution. To ensure that the estimated rate is positive, a log linear function is used to relate covariates, $\mathrm{X}_{\mathrm{i}}$, to the expected value of $\mathrm{Y}_{\mathrm{i}}$. That is:

$$
\lambda_{i t}=\exp \left[\beta^{\prime} X_{i t}\right]
$$

The Poisson model produces reliable and consistent estimates under a various set of conditions (see Gourieroux et al., 1984) but relies on the assumption that the mean and the variance of the dependent variable are equal and, thus, is exposed to the problem of overdispersion. The negative binomial model allows correcting for overdispersion, but remains sensitive to the underlying process that generates the events (Metcalfe \& Thompson, 2006). Moreover, correlations across countries as well as within each country over time may bias the estimation of the coefficients reported. After detecting the presence of overdispersion in our data, we decided to deal with the abovementioned problems by employing a population-averaged panel negative binomial estimator and opting for an

\footnotetext{
${ }^{12}$ The piecewise specification allows a semi-parametric specification of the hazard rate: while it is required to remain constant within each piece, it is allowed to vary across them. The robustness of our findings was however tested by employing alternative specifications (i.e., Exponential and Weibull). The results obtained turned out to be similar to those presented here.
} 
exchangeable working correlation matrix and for reporting robust standard errors (see Zelner et al., 2009). ${ }^{13}$ QIC fit statistics, obtained from the routine available in STATA, are reported in Table 3.

\section{RESULTS}

Table 3 reports the estimates of the event history models concerning the hazard rates of adoption of a multiplex cinema for the European countries included in our database during the period 1980-2001. Slovenia, Estonia, Croatia, Latvia and Lithuania were omitted from this analysis as we lack information on their standing in the world system. The first column presents the estimates of the model including the controls and the test concerning the impact of European density (see H1). The model specification shown in the second column includes the effect of Normative distance (H2). The full model specification includes the Regulative distance variable and tests its impact on the countrylevel rates of adoption of the first multiplex cinema (H3).

-----Insert Table 3 about here-----

The estimates obtained from the first model presented in Table 3 do conform to our expectations. The period effects inform us that the hazard of adopting the first multiplex across Europe followed a rather complex pattern of diffusion over time. As expected, countries that belonged to the Eastern block experienced a lower hazard of adoption compared to Western nations. The level of gross domestic product per person did not affect the hazard of adoption of multiplexes across Europe, whereas the country's standing in the world system is associated with a higher hazard of adoption (but only in Model 1). In line with Hypothesis 1, the more multiplex cinemas are active in other European countries, the higher the hazard of adoption of such an organizational form by the focal country.

The second model of Table 3 is meant to test the effect of normative distance. The impact of normative distance appears aligned with Hypothesis 2. According to the estimates obtained, a country belonging to the Latin European group like France or Italy was 68 per cent less likely than the United Kingdom (i.e., the Anglo cultural block) to adopt a multiplex cinema. This result is robust to the addition of the variable controlling for the Economic Freedom of the focal country (see Model 3). The

\footnotetext{
${ }^{13}$ The results obtained when employing an AR(1) correlation matrix turned out to be qualitatively similar.
} 
coefficient estimate of this variable does not support our hypothesis. We interpret this result as possibly related to the missing values of this variable in non-adopting countries (e.g., ex-Communist countries and ex-Yugoslavia ones) during the years before 1990 (i.e., at the time in which they were the most distant from the ideal of economic freedom). We double-checked this by re-running the analyses for a smaller sample that includes only the countries in which the information on the economic freedom variable is complete. Indeed, the fourth column of Table 3 reports the estimates of our model that provide support to our intuition. The fifth column of Table 3 checks the impact of missing values concerning the standing of the country in the world system. While the results concerning normative distance appear robust across the various model specifications, the same cannot be concluded about the effect of economic freedom, still affected by missing data concerning critical countries and critical years. This trend of results provides limited support to Hypothesis 3 .

\section{-----Insert Table 4 about here-----}

Table 4 provides the GEE estimates of the negative binomial models for the within-country founding rates. Remember that several countries are excluded from these analyses because of the presence of only one or even none multiplex. ${ }^{14}$ Slovenia was omitted from this analysis as we lack information on its position in the world system. Model 1 provides support to the arguments concerning the impact of supra-national legitimation as well as to those related to the effect of national density. Both estimates are positive and statistically significant. Moreover, the negative effects of normative distance on founding rates are evident, whereas the expected positive effect of economic freedom does not materialize. Model 2 checks whether the linear trend of density-dependent legitimation may be replaced by a cubic specification. Indeed, the improvement in the fit of the model to the data supports this claim. As predicted by Hypothesis 4, the impact of the national density of multiplexes on the founding rates exhibits a slowdown. In particular, the estimates of the polynomial specification of density-dependent legitimation suggest a significant decrease (see the quadratic term of density) in the founding rates in between an initial (i.e., linear term of density) and a late increase (i.e., cubic term of

\footnotetext{
${ }^{14}$ Estonia, Latvia, Lithuania, Luxemburg, Russia, Croatia, Bulgaria, Malta, and Romania were excluded.
} 
density). ${ }^{15}$ Figure 3 plots the multiplier of the founding rate for the complete range of the national density variable. Notice that the impact of European density remains significant. ${ }^{16}$

-----Insert Figure 3 about here-----

Model 3 and 4 test the impact of the polynomial specification of multiplex density over different values of normative distance and of economic freedom. As expected, the complex effect of national density on founding rates appears amplified by normative distance (H4a); the moderating effect of economic freedom, however, does not seem apparent (H4b). ${ }^{17}$ Figure 4 plots the results at one standard deviation below and at one standard deviation above the mean of the normative distance variable. The coefficient estimates of the uncentered model have been used for drawing of the plot. ${ }^{18}$ As the figure illustrates, the process of within country diffusion exhibited substantial fluctuations especially among normatively-distant countries. ${ }^{19}$

-----Insert Figure 4 about here-----

Robustness Checks

\footnotetext{
${ }^{15}$ As a considerable number of local multiplexes is part of cinema chains, in analyses not reported here we replaced the variable multiplex density with the number of organizations owing at least 2 establishments in the focal country. The results obtained turned out to be qualitatively similar to those presented in Table 3 . The extreme correlation between these variables (.90) makes hard to disentangle the two effects though.

${ }^{16}$ As multicollinearity may threaten our estimates, in analyses not reported here, we employed orthogonal polynomials. The trend of findings obtained turned out to be similar to that reported here.

${ }^{17}$ Analyses not reported here indicate that when using a different specification of the regulative distance construct - i.e., by employing the measure of the heritage foundation (see methods section), the results of the interactions appear as expected and statistically significant. As this alternative measure of economic freedom appears partial, we invite caution in interpreting such results.

${ }^{18}$ In the uncentered specification the main effects of the polynomial specification of density are not statistically significant. This result is fully aligned with our theory which suggest that in countries fully aligned with US values and beliefs, camouflage and opposition should not be manifest. The coefficient estimate of the main effect of normative distance is -.33 with p.<.05.

${ }^{19}$ Recent articles by Hoetker (2007) and Zelner (2009) discuss the interpretation of interaction effects in nonlinear models. According to the procedure proposed by Zelner, the estimated coefficients and their standard errors are used to make 1000 draws, generating 1000 sets of regression coefficients, whose distribution yields the same mean and standard error as the initial estimates. The expected values of the dependent variable are calculated by employing the sets of simulated coefficients and the predictors, set at their sample mean values. An unconstrained (country level) fixed effect model (Allison and Waterman, 2002) was employed as no panel command (e.g., xtnbreg or xtgee) is available in this routine. We then use the Intgph command to visualize and interpret the statistical significance of the simulation (Zelner, 2009). The estimates obtained from the unconstrained models in which normative distance is interacted with density indicate that each of three interaction coefficients appears statistically significant in most of the data points of our sample.
} 
Several empirical checks were run to investigate our interpretation of the moderating effects to

Hypothesis 4. The results of three of them are reported in the Appendix. ${ }^{20}$ First, as normative distance is a powerful antecedent of the timing of entry of the multiplex form in the focal country, we employed year of entry variable as an alternative moderator. The first column in the Appendix reports the results obtained from this procedure, which appear aligned with those of Model 3. A graphical inspection of the interaction effect provided support to our interpretation. Second, an interesting proxy of the normative/cultural distance of the focal country from the US may be its receptiveness to McDonald's fast food restaurants. Indeed, various experts from the cinema industry compared the diffusion of multiplexes to the success of McDonald's (e.g., Evans, 2003; Bogani, 2008). While the yearly data on the diffusion of McDonald's restaurants proved to be unavailable, we manage to find the information concerning the year of establishment of first McDonald's restaurant for every country included in our sample. The Appendix reports the results obtained by employing this variable as moderator of the effects of national density. The coefficient estimates -- albeit weaker - appear aligned with our arguments. Last, as the market share of US movies may be argued to be a good predictor of openness of the focal country to the values and norms embodied by the multiplex form, we also collected such information. Our main source was Media Salles, complemented by bibliographic search. As expected (see last column in the Appendix), the larger the market share of US movies in the focal country, the weaker the effects of each of three mechanisms captured by the polynomial specification of density. The substantial number of countries lacking information on this variable (i.e., 6 out of 20) invites however particular attention in the interpretation of these results and led us to avoid employing this moderator in the main models of the paper. ${ }^{21}$

\section{DISCUSSION AND CONCLUSIONS}

\footnotetext{
${ }^{20}$ The variables involved in the interactions reported in the Appendix have been mean-centered.

${ }^{21}$ It is true that the more extensive use of camouflage among late entrants remains hardly observable in our data. Multi-screen theaters however represented an initial and temporary response of local cinema owners to the threat of multiplexes of becoming established and may be argued to represent a camouflaged adoption of the cultural logic of multiplexes. Building on this arguments, we went back to our data sources and collected further information concerning the number of multi-screen theatres in each of the country. Indeed, GEE regression which employ the same set of control variables reported in Table 4 indicate that the larger the normative distance of the focal country, the larger the number of multiscreen theaters observed therein. The opposite however holds true when considering economic freedom. The substantial number of missing data in the number of multiscreen variables (i.e., about 30\%) invites however caution in the interpretation of these results.
} 
New organizational forms when theorized with reference to global norms of efficiency and progress, may diffuse easily thanks to the cultural construction of the modern world system as a "relatively unified cultural system and a densely linked economy ... without a centralized political system” (Meyer \& Hannan 1979b: 298). However, because meanings are organized in landscapes that reflect and are shaped by global cultural processes and by the institutional logics of the importing societies (Friedland \& Alford, 1991), a complex interaction between global cultural scripts and local beliefs, norms and values marks the process of within-country legitimacy of such forms. Our findings demonstrate that the first adoption of a multiplex was retarded by the normative and regulative distance of the focal country from the norms and values embodied by the multiplex form. As for the within-country analyses, our qualitative and quantitative findings indicate that cultural differences shaped legitimation as follows: contestation hindered the local diffusion of multiplexes, whereas camouflage and the enactment of global cultural-cognitive scripts supported it. The normative distance of the focal country contributed to amplify these dynamics. Interestingly enough, while in some of our models economic freedom accelerated the adoption of the multiplex form, this variable failed to significantly affect within-country diffusion. Theoretically, we interpret the results of our study as indicating that cultural-cognitive and normative differences -- rather than regulative ones -- were the critical triggers of the mechanisms advanced. ${ }^{22}$

The present paper contributes to the ecology literature by showing that the legitimation of an internationally diffusing organizational form involves a complex interaction between global and local forces, in which the cognition of relevant audiences appears to be filtered by cultural differences. Institutionally speaking, only when a new form is recognized as a distinct category, the 'real' process of legitimation begins, albeit with an uncertain finale (see, e.g., McKendrick et al., 2003). When removing camouflage from the picture, our results appear consonant with those of Dobrev and his colleagues (2006) who found that the benefits of cognitive legitimacy emerge only upon the establishment of a collective identity -- a process accompanied by the reduced success of the members of the emerging organizational form. The hypothesis advanced by the authors is tested with reference

\footnotetext{
${ }^{22}$ As Scott (2001: 60) put it: "Entrenched power is, in the long run, helpless against the onslaught of opposing power allied with more persuasive ideas" - see also Ruef and Scott (1998).
} 
to the mortality rates of financial cooperative banks in Singapore and to the opposition of local commercial banks. No camouflage was observed in that context. Future research should elaborate on the conditions under which camouflage is employed and becomes a successful mechanism to back up the initial diffusion of an alien organizational form. By focusing on the hindering and supporting mechanisms to the legitimation of a rationalized organizational form, our study contributes also to world polity research -- usually concentrated on first-time adoptions (e.g., Meyer et al., 1977; Wotipka \& Ramirez, 2008) or on local opposition as delaying or impeding implementation (e.g., Hafner-Burton \& Tsutsui, 2005; Weber et al., 2009) -, further improving our understanding of implementation processes. Strong opposition, however, may also lead to the repeal of an organizational form. Incidentally, the temporary nature of contestation may be explained in terms of lack of agreement on the objectives among the members of a social movement, or to their inability to portray the opposition as entailing a substantial value cleavage in the society (see Meyer \& Staggenborg, 1996), or to the lack of a favorable political opportunity structure (for a review see Tarrow, 1988). Future research should clarify the conditions under which temporary opposition may lead to the repeal of a form.

In more general terms, the results of the present study demonstrate the fruitfulness of a dialogue between institutional theory and organization ecology. We decided to undertake this route by revisiting a building block of the organization ecology literature: density-dependent legitimation (see Carroll \& Hannan, 2000, for a review). In so doing, we focused our attention on the limits of a onedimensional and culture-free conception of legitimation and advanced a new model specification of density-dependent legitimation generalizable to any internationally diffusing form potentially at odds with the beliefs, norms and values of the importing context. Notice that the dialogue among these theories is even more natural today as ecologists appear more inclined to inject social constructivism in their theorizing (Hannan et al., 2007) and start to conceive legitimation as a multidimensional process (for a review see Hannan, 2010). Our research shows that even if the cognitive recognition of the form had taken place, struggles may unfold on other terrains, and only a multilevel, multidimensional and multi-stage conception of legitimacy allows grasping the entire process of legitimation (e.g., Ruef \& Scott, 1998; Scott, 2001; Meyer et al., 2006). 
A possible critique to the present paper pertains to the generalizability of its claims. While the hindering and supporting mechanisms discussed here may hold true for any organizational form theorized along global scripts of modernity but imbibed with values and norms distant from those of the receiving context, a comprehensive inventory of the possible mechanisms at work is presented in Figure 5. This theoretical exercise is largely inspired by the qualitative evidence collected for this research project. In particular, our goal is to discuss the mechanisms that may favor or hinder the adoption and the subsequent within-country diffusion of a rationalized organizational form among early and late adopting countries (we lean on Strang \& Meyer 1993; Czarniawska \& Joerges 1996; Campbell 2004, 2005; Davis \& Marquis 2005; Simmons et al. 2006; Delmestri 2009; Ansari et al. 2010; Ingram et al. 2010). Economic mechanisms - above and beyond institutional ones -- are discussed as well and may be argued to be especially relevant when considering "private" organizational forms ${ }^{23}$ (see also Ingram et al. $2010^{24}$ and Delmestri \& Walgenbach 2009). -----Insert Figure 5 about here-----

The mechanisms at play in culturally and institutionally closer countries are consonant with those already established in the literature. Institutional mechanisms of theorization, and of diffusion of templates among professional circles, together with the typical information cascades and vicarious learning described by economists, may favor the adoption of the new organizational form. Subsequent within-country diffusion, driven by the seizing of new opportunities by indigenous entrepreneurs and foreign firms, has to overcome oligopolistic market barriers and the opposition of the incumbent entrepreneurs. Cultural fit, regulative matching and emulation are the mechanisms at play during the early diffusion; robust design, trait-based imitation, proselytizing and aggressive marketing are necessary complimentary mechanisms. In this phase, the new form has, in addition, to overcome the categorical imperative (Zuckerman, 1999), and legitimation can only be successful if global theorization is locally validated to accommodate the new category in front of the relevant audiences.

\footnotetext{
${ }^{23}$ We thank an anonymous reviewer for highlighting this issue.

24 "[C]orporations look more like the strategic actors of game theory than do the states which are more often the targets in social movement analysis" (p. 33).
} 
The remaining part of the legitimation process can be understood with reference to the well known ecological narrative -- i.e., the forms gains cognitive legitimacy and the status of taken-for-granted.

The dynamics of culturally and institutionally more distant countries are possibly more novel and interesting. Initial adoption may be retarded due to the existence of norms, laws and regulations restricting free establishment. However, the theorization of the new form at the global level and the examples of foreign success spread among professional circles, offer investors more arguments to oppose the counter-framings of the form as harmful to national culture and interests, and to give them enough strength to obtain a repeal of restrictive laws. Early diffusion requires robust designs from the inception, and may be characterized by camouflage; in some cases, first adoption may require “institutional delinquency” (Guérard \& Langley, 2008). Lobbying local governments is probable a counter-mechanism that will affect within-country diffusion during this phase. The first slow down may be triggered by cultural misfit and negative framing by local interest groups, all hindering mechanisms. Such opposition may even push towards the retrenchment of laws supporting the freedom of establishment (as was the case in France in our study). Overcoming such a strong opposition requires entrepreneurs to rely on the logics of progress and modernity or to translate the form to adapt it to local expectations (e.g., by limiting number of screens, closeness to city centers, architectural features). Translation of the original prototype, coupled with achieved market dominance and the deployment of soothing rhetoric (such as sustaining the local movie-theater industry), would continue in the second diffusion phase to foster within-country legitimation. Opposition may entrench into lobbying for laws to protect the engendered species of traditional indigenous movie theaters.

A few limitations of this paper are worth discussing. We consider each of them as a fruitful avenue of development of the present study. First, to describe the normative opposition encountered by multiplexes we relied on qualitative evidence collected through interviews with relevant stakeholders or archival data. A more direct measure of the local conflict ensuing may however be obtained from a textual analysis of the articles published in national media (e.g., Deephouse, 1996). Second, much attention has to be devoted to disentangle the possible sources of opposition to the emergence of the new form (e.g., Anti-Americanism, cultural opposition). Data concerning the 
reactions of multiple audience members (e.g., regulators, journalists, customers) may be useful to directly test the mechanisms of legitimation illustrated here. Last, the pattern of density-dependent legitimation observed here may also occur in contexts in which the diffusing element touches upon any core dimensions of a local identity. Instances of opposition may also be traced in the corporate governance models that disrupt institutions (e.g., shareholder value in Germany), or in policies that introduce new organizational forms that clash with deep seated cultural values (e.g., privatization of water supply or health care). Future research should clarify the conditions under which a slowdown, a retrenchment, or a repeal of the alien organizational form is likely to take place. 


\section{LITERATURE}

Aldrich, H. E. \& Fiol, C. M. 1994. Fools rush in? The institutional context of industry creation. Academy of Management Review, 19: 645-670.

Allison P. D. \& R. Waterman, 2002. Fixed effects negative binomial regression models. Sociological Methodology, 32: 247-265.

Ansari, S., P. C. Fiss, \& Zajac, E. J. 2010. Made to fit: How practices vary as they diffuse. Academy of Management Review, 35(1): 67-92.

Barkema, H.G., Bell, J. H. J., Pennings, J. M. 1996. Foreign entry, cultural barriers, and learning. Strategic Management Journal, 17(2): 151-166.

Bianchini, F. 2004. The cultural impacts of globalization and the future of urban cultural policies. In C. Johnstone \& M. Whitehead (eds), New horizons in British urban policy: Perspectives on New Labour's urban renaissance. London: Ashgate.

Blin, E. 1999. Les multiplexes cinématographiques: un nouvel enjeu territorial. Annales de Géographie, 606. Paris: Armand Colin: 151-169.

Bourdieu, P. 2001. Contre-feux 2: Pour un mouvement social européen. Paris: Raisons d'agir.

Campbell, J. L. 2004. Institutional change and globalization. Princeton University Press.

Campbell, J. L. 2005. Where do we stand? Common mechanisms in organizations and social movements research. In G. F. Davis, D. McAdam, W. R. Scott, M. N. Zald (eds) Social movements and organization theory: 41-68. Cambridge University Press, New York.

Carroll, G. R., \& Hannan, M. T. 2000. The demography of corporations and industries. Princeton University Press.

Caves, R. 2000. Creative industries: Contracts between art and commerce. Cambridge, MA: Harvard University Press.

Chaudhuri, S. 2005. Contemporary world cinema: Europe, the Middle East, East Asia and South Asia. Edinburgh: Edinburgh University Press.

Cohen J., Cohen P., West S., \& Aiken L. 2003. Applied multiple regression/correlation analysis for the behavioral sciences. Mahwah: L. Erlbaum Associates. 
Czarniawska, B., \& Joerges, B. 1996. Travels of ideas. In B. Czarniawska, \& G. Sevón (eds):

Translating organizational change: 13-48. Water de Gruyter, Berlin and New York, 13-48.

Davis, G. F., \& Marquis, C. 2005. Prospects for organization theory in the twenty-first century: Institutional fields and mechanisms. Organization Science, 16: 332-343.

Deephouse, D. L. 1996. Does isomorphism legitimate? Academy of Management Journal, 39(4): 1024-1039.

Delios, A., \& Henisz, W. J. 2003. Political hazards, experience, and sequential entry strategies: The international expansion of Japanese firms, 1980-1998. Strategic Management Journal, 24: $1153-1164$.

Delmestri, G. 1993. The cinema exhibition industry in Europe between evolution and revolution. Proceedings of the 2nd International Conference on Arts and Management Groupe HEC, France 23-25 June.

Delmestri, G. 2009. Institutional streams, logics, and fields. Research in the Sociology of Organizations, 27: 99-128.

Delmestri, G., \& Walgenbach, P. 2009. Interference among institutional influences and technicaleconomic conditions: The adoption of the Assessment Center in French, German, Italian, UK and US international firms. International Journal of Human Resource Management, 20(4): 885911.

Demil, B., \& Leca, B. 2003. Architecture de marché et regulation dans l'explotation cinématographique française. Revue Française de Gestion, 142: 229-252.

Dequech, D. 2003. Cognitive and Cultural Embeddedness: Combining Institutional Economics and Economic Sociology. Journal of Economic Issues, 37(2): 461-70.

DiMaggio, P. J., \& Powell, W.W. 1983. The iron cage revisited. Institutional isomorphism and collective rationality in organizational fields. American Sociological Review, 48: 147-60.

Djelic, M-L., \& Sahlin-Andersson, K. (eds) 2006. Transnational governance. Institutional dynamics of regulation. Cambridge: Cambridge University Press.

Djelic, M.-L. 1998. Exporting the American model: The postwar transformation of European business. Cambridge, Cambridge University Press. 
Dobrev, S. D., Ozdemir, S. Z., \& Teo, A. C. 2006. The ecological interdependence of emergent and established organizational populations: Legitimacy transfer, violation by comparison, and unstable identities. Organization Science, 17: 577-97.

Drori, G. S. 2008. Institutionalism and globalization studies. In R. Greenwood, Ch. Oliver, K. Sahlin, \& R. Suddaby (eds): The Sage handbook of organizational institutionalism: 449-472. Los Angeles, London, New Delhi, Singapore: Sage Publications.

Drori, G. S., Jang, Y. S., \& Meyer, J. W. 2006. Sources of rationalized governance: cross-national longitudinal analyses, 1985-2002. Administrative Science Quarterly, 51: 205-229.

Drori, G. S., Meyer, J.W., \& Hwang, H. 2006. Introduction. In G.S. Drori, J.W. Meyer, \& H. Hwang (eds): Globalization and organization: World Society and organizational change: 1-24. Oxford: Oxford University Press.

Echambadi, R., \& Hess, J. 2007. Mean-centering does not alleviate collinearity problems in moderated multiple regression models. Marketing Science, 26: 438-445.

Evans, G. 2003. Hard-branding the cultural city. From Prado to Prada. International Journal of Urban and Regional Research, 27(2): 417-440.

Fiss, P. C., \& Zajac, E. J. 2004. The diffusion of ideas over contested terrain: The (non)adoption of a Shareholder Value orientation among German firms. Administrative Science Quarterly, 49: 501534.

Fombrun, C., \& Shanley, M. 1990. What's in a name? Reputation building and corporate strategy. Academy of Management Journal, 33: 233-258.

Frank, D.J., Hironaka, A. \& Schofer, E. 2000. The Nation-State and the natural environment over the twentieth century. American Sociological Review, 65(1): 96-116.

Friedland, R., \& Alford, R. R. 1991. Bringing society back in: symbols, practices, and institutional contradictions. In W. W. Powell, \& P. J. DiMaggio (Eds), The New institutionalism in organizational analysis: 232-263 Chicago and London: The University of Chicago Press.

Friedson, E. 2001. Professionalism: The third logic. Cambridge: Polity Press.

Geppert, M., Matten, D., \& Walgenbach, P. 2006. Transnational institution building and the multinational corporation: an emerging field of research. Human Relations, 59(11): 1451-65. 
Gleditsch, K. S. 2002. Expanded trade and GDP data. Journal of Conflict Resolution, 46: 712-24.

Gourieroux, C., A. Monfort, \& A. Trognon 1984. Pseudo maximum likelihood methods: Applications to poisson models. Econometrica, 52, 701-720.

Guérard, S, \& Langley, A. 2008. Translating bandwagon technology in two institutional contexts: the diffusion of the PET scanner in Quebec \& in Switzerland. Academy of Management Annual Meeting, California, Anaheim, August.

Gwartney, J. \& Lawson, R. 2006. Economic freedom of the world: 2006 annual report. Vancouver: The Fraser Institute.

Hafner-Burton, E. \& K. Tsutsui. 2005. Human rights in a globalizing world: The paradox of empty promises. American Journal of Sociology, 110: 1373-411.

Hannan, M. T. 2010. Partiality of memberships in categories and audiences. Annual Review of Sociology, 36: 159-181.

Hannan, M. T., \& Carroll, G. R. 1992. Dynamics of organizational populations: Density, legitimation, and competition. New York: Oxford University Press.

Hannan, M. T., Carroll, G. R., Dundon, E. A., \& Torres, J. C. 1995. Organizational evolution in a multinational context: entries of automobile manufacturers in Belgium, Britain, France, Germany, and Italy. American Sociological Review, 60: 509-28.

Hannan, M. T., Polos, L. , \& Carroll, G. R. 2007. Logics of organization theory: audiences, codes and ecologies. Princeton University Press.

Hannan, M., \& Freeman, J. 1989. Organizational Ecology. Cambridge, Mass: Harvard University Press.

Hannan, M.T. \& Freeman, J. 1977. The population ecology of organizations. American Journal of Sociology, 82(5): 929-964.

Hargadon, A. B., \& Douglas, Y. 2001. When innovations meet institutions: Edison and the design of the electric light. Administrative Science Quarterly, 46: 476-501.

Haveman, H. A, \& David, R. J. 2008. Ecologists and institutionalists: friends or foes? In R.

Greenwood, Ch. Oliver, K. Sahlin, R. Suddaby (eds): The Sage handbook of organizational institutionalism: 573-595. Los Angeles, London, New Delhi, Singapore: Sage Publications. 
Haveman, H. A, \& Rao, H. 1997. Structuring a theory of moral sentiments: Institutional and organizational coevolution in the early thrift industry. American Journal of Sociology, 102: 1606-1651.

Haveman, H. A. 1993. Follow the leader: Mimetic isomorphism and entry into new markets. Administrative Science Quarterly, 38: 564-592.

Henisz, W. J., \& Delios, A. 2001. Uncertainty, imitation, and plant location: Japanese multinational corporations, 1990-1996. Administrative Science Quarterly, 46(3): 443-475.

Henisz, W. J., Zelner, B.A., \& Guillén, M.F. 2005. The worldwide diffusion of market-oriented infrastructure reform, 1977-1999. American Sociological Review, 70(6): 871-897.

Hoetker G. 2007. The use of logit and probit models in strategic management research: Critical issues. Strategic Management Journal 28(4): 331-343.

Hofstede, G. 1980. Culture's consequences: International differences in work related values. Beverly Hills, CA: Sage.

Hsu, G., \& Hannan, M. T. 2005. Identities, genres, and organizational forms. Organization Science, 16: 474-490.

Hwang, H. \& Powell, W.W. 2005. Institutions and entrepreneurship. In S.A. Alvarez, R. Agarwal \& O. Sorenson (Eds), Handbook of entrepreneurship research: Disciplinary perspectives: 201232. New York: Springer.

Ingram, P., \& Rao, H. 2004. Store wars: The enactment and repeal of anti-chain-store legislation in America. American Journal of Sociology, 110(2): 446-87.

Ingram, P., Yue L.Q. \& H. Rao. 2010. Trouble in store: probes, protests and store openings by WalMart: 1998-2005. American Journal of Sociology, 116(1): 53-92.

Jepperson, R.L., \& Meyer, J.W. 1991. The public order and the construction of formal organizations. In W. W. Powell, \& P. J. DiMaggio (eds): The New Institutionalism in organizational analysis: 204-231. Chicago and London: The University of Chicago Press.

Kim, W. C., \& Mauborgne, R. 1997. Value innovation: the strategic logic of high growth. Harvard Business Review. January-February, 103-112. 
Kogut B., \& Singh H. 1988. The effect of national culture on the choice of entry mode. Journal of International Business Studies, 19: 411-432.

Koo, J.-W., \& Ramirez, F. O. 2009. National incorporation of global human rights: Worldwide adoptions of national human rights institutions, 1966-2004. Social Forces, 87: 1321-54.

Kostova, T. 1999. Transnational transfer of strategic organizational practices: A contextual perspective. Academy of Management Review, 24: 308-324.

Kupfer, J. 1990. From edifice to device. Architecture of disengagement. Technology in Society, 12: 319-332.

Maunder, P. 1996. New entry: ice cream and the big screen. Economic Review, 13(3). http://www.soton.ac.uk/ peters/er/indec.htm

Mazza, C., Sahlin Andersson, K., \& Strandgaard Pedersen, J. 2005. European constructions of an American model. Management Learning, 36(4): 471-491.

McDonald, P. 2006. Plexing the Nation: transforming the film exhibition industry in Britain. Unpublished Working Paper, Roehampton University.

McDonald, P. 2010. What's on? Film programming, structured shoice and the production of cinema culture in contemporary Britain. Journal of British Cinema and Television, 7(2): 264-298

McKendrick, D.G. \& Carroll, G.R. 2001. On the genesis of organizational forms: Evidence from the market for disk arrays. Organizational Science 12(6): 661-682.

McKendrick, D.G., Jaffee, J., Carroll, G.R. \& Khessina, O.M. 2003. In the bud? Disk array producers as a (possibly) emergent organizational form. Administrative Science Quarterly, 48(1): 60-93.

Metcalfe C. \& S.G. Thompson, 2006. The importance of varying the event generation process in simulation studies of statistical methods for recurrent events. Statistics in Medicine, 25: 165179.

Meyer D. S. \& S. Staggenborg. 1996. Movements, countermovements, and the structure of political opportunity. American Journal of Sociology, 101: 1628-1660.

Meyer J. W., \& Rowan, B. 1977. Institutional organizations: formal structure as myth and ceremony. American Journal of Sociology, 83, 340-63 
Meyer, J. W. 2008. Reflections on institutional theories of organizations. In R. Greenwood, Ch. Oliver, K. Sahlin, R. Suddaby (eds): The Sage handbook of organizational institutionalism: 790-811. Los Angeles, London, New Delhi, Singapore: Sage Publications.

Meyer, J. W., Boli, J., Thomas, G. M., \& Ramirez, F. O. 1997. World Society and the Nation-State. American Journal of Sociology, 103: 144-181.

Meyer, J. W., Drori, G. S., \& Hwang, H. 2006. Conclusion. In G. S. Drori, J.W. Meyer, \& H. Hwang, H. (eds): Globalization and organization: World Society and organizational change: 258-274. Oxford: Oxford University Press.

Meyer, J. W., \& Hannan, M. T. 1979a. National development and the world system: Educational, economic, and political change, 1950-1970. University of Chicago Press.

Meyer, J. W., \& Hannan, M. T. 1979b. Issues for further comparative research. In J. Meyer \& M. Hannan (eds), National Development and the World System: 297-308, University of Chicago Press.

Meyer, J. W., Ramirez, F. O., Frank, D, \& Schofer, E. 2007. Higher Education as an Institution. In P. Gumport (ed), The Sociology of Higher Education. Baltimore, MD: The Johns Hopkins University Press.

Meyer, J. W., Rubinson, R. Ramirez, F. O., \& Boli-Bennett, J. 1977. World educational revolution, 1950-1970. Sociology of Education, 50: 242-258.

Paxton P., M. Hughes \& J. Green. 2006. The International Women's Movement and Women's Political Representation, 1893-2003 American Sociological Review, 71: 898-920.

Peng, M. W., Hill, C., \& Wang, D. 2000. Schumpeterian dynamics versus Williamsonian considerations: A test of export intermediary performance. Journal of Management Studies, 37(2): 167-184.

Peng, M. W., Zhou, Y., York, A.S. 2006. Behind make or buy decisions in export strategy: A replication and extension of Trabold. Journal of World Business, 41: 289-300

Perotti, F. 2004. Nascita e diffusione dei cinema multiplex in Italia. Tesi di Laurea, Bocconi University. Tutor G. Delmestri. 
Potts, J., Cunningham, S. 2008. Four models of the creative industries. International Journal of Cultural Policy, 14(3): 233 - 247.

Ronen, S., \& Shenkar, O. 1985. Clustering countries on attitudinal dimensions: A review and synthesis. Academy of Management Review, 10: 435-455.

Ronen, S., \& Shenkar, O. 2008. Culture Clustering Revisited: A Nested Meta-Analysis. Unpublished manuscript.

Ruef, M. 2000. The emergence of organizational forms: a community ecology approach. American Journal of Sociology, 106: 658-714.

Ruef, M., \& Scott, W. R. 1998. A multidimensional model of organizational legitimation: hospital survival in changing institutional environment. Administrative Science Quarterly, 43: 877-904.

Simmons, B.A., \& Elkins, Z. 2004. The globalization of liberalization: policy diffusion in the international political economy. American Political Science Review, 98: 171-189.

Scott, W. R. 2001. Institutions and organizations. Second edition. Thousand Oaks, CA: Sage.

Shenkar, O. 2001. Cultural distance revisited: towards a more rigorous conceptualization and measurement of cultural differences. Journal of International Business Studies, 32(3): 519-535.

Simmons, B. A., Dobbin, F., \& Garrett, G. 2006. Introduction: The international diffusion of Liberalism. International Organization, 60: 781-810.

Strang, D., \& Tuma, N. B. 1993. Spatial and temporal heterogeneity in diffusion. American Journal of Sociology, 99: 614-639.

Strang, D., \& Meyer, J. W. 1993. Institutional conditions for diffusion. Theory and Society, 22: 487511.

Tarrow, S. 1988. National politics and collective action: Recent theory and research in Western Europe and the United States. Annual Review of Sociology, 14: 421-440.

Thornton, P. 2004. Markets from culture: institutional logics and organizational decisions in higher education publishing. Stanford, CA: Stanford University Press.

van Rossem, R. 1996. The world system paradigm as general theory of development: A crossnational test. American Sociological Review, 61: 508-527. 
Weber, K., Davis, G. F., \& Lounsbury, M. 2009. Policy as myth and ceremony: The global spread of stockmarkets, 1980-2005. Academy of Management Journal, 52(6): 1319-1347.

Weber, M. 1978/1921. Economy and society. An outline of interpretive sociology. Edited by G. Roth \& C. Wittich. Berkley et al., University of California Press.

Weick, K. E. 1995. Sensemaking in organizations. Thousand Oaks, London \& New Delhi, Sage Publication.

Wezel, F.C. \& Lomi, A. 2003. The organizational advantage of nations: an ecological perspective on the evolution of the motorcycle industry in Belgium, Italy and Japan, 1894-1993. In J.A.C. Baum, \& O. Sorenson (Eds), Geography and strategy. Advances in Strategic Management, 20: 359-392. Greenwich CT: Jai Press.

Whitley, R. 1994. Dominant forms of economic organization in market economies. Organization Studies, 15(2): 153-182.

Wotipka, C. M. \& Ramirez, F. O. 2008. World society and human rights: An event history analysis of the convention on the elimination of all forms of discrimination against women. In A. Beth Simmons, F. Dobbin, G. Garrett (eds). The global diffusion of markets and democracy: 303343. Cambridge: Cambridge University Press.

Xu, D. \& Shenkar, O. 2002. Institutional distance and the multinational enterprise, Academy of Management Review, 27(4): 608-618.

Xu, D., Pan, Y., \& Beamish, P.W. 2004. The effect of regulative and normative distances on MNE ownership and expatriate strategies. Management International Review, 44(3): 285-307.

Zelner, B.A. 2009. Using simulation to interpret results from logit, probit, and other nonlinear models. Strategic Management Journal, 30(12): 1335-1348.

Zelner, B.A., Henisz, W.J., \& Holburn, G.L.F. 2009. Contentious implementation and retrenchment in neoliberal policy reform: The global electric power industry, 1989-2001. Administrative Science Quarterly, 54(3): 379-412.

Zuckerman, E. W, \& Kim, T.-Y. 2003. The critical trade-off: Identity assignment and box-office success in the feature film industry. Industrial and Corporate Change, 12: 27-67. 
Zuckerman, E. W. 1999. The categorical imperative: Securities analysts and the illegitimacy discount. American Journal of Sociology, 104(5): 1398-1438.

\section{Industry Data Sources}

Aas, N. K. 1995. 100 years of cinema exhibition in Norway - a historical profile. www.mediasalles.it. Anonymous. 2007. Multiplex cinemas boost India's movie mania. www.canada.com based on Reuters. Association Cinématographique Suisse- 1995. 100 years of cinema exploitation in Switzerland - a historical profile. www.mediasalles.it.

Bähr, R., \& Neckermann, G. 1997. Cinema structure and multiplex development - results of a survey of cinemas and a study of the impact of the new picture palaces. Original publication: Kinostruktur und Multiplexentwicklung, MediaPerspektiven, 3, Frankfurt am Main.

Bedarida, C. 1996. Deux projets de multiplexe divisent les villes de Montpellier et de Lattes. LeMonde.fr, December 26.

Bipe Conseil. 1994. Mouvements d'intégration verticale et exploitation cinématographique en Europe. Unpublished manuscript realized for Media Salles, January.

Bogani, G. 2008. Il cinema come un McDonald's, un multiplex da 2200 posti apre nel centro di Firenze. Affaritaliani.it, November 17th.

Borsboom, E. 1995. 100 years of cinema exhibition in the Netherlands - a historical profile. www.mediasalles.it.

Calzini, M. 1995. 100 years of cinema exhibition in Italy - a historical profile. www.mediasalles.it.

Castellina, L. 2010. Europe must become conscious of its own culture. Rosa Luxemburg Foundation, Brussels Office, Policy Paper July.

Chantry, C. 1999. Les anti-multiplexe vont descendre dans la rue. A Conflans-Sainte-Honorine le projet crispe les débats. LeParisienne.fr, May 12th.

Christie, I. 1995. 100 Years of cinema exhibition in Britain - A historical profile. Published by MEDIA Salles, Media Programme, European Union

CNC. 2000. Les spectateurs des multiplexes. Service des études, des statistiques et de la prospective. www.cnc.fr. 
Communauté française de Belgique. 1997. The film industry in Belgium. Original publication in Annuaire de l'audiovisuel 1997, Tome II, Bruxelles, 1997. www.obs.coe.int/oea_publ/eurocine/1424.html.fr.

Couling, K., \& Grummit, K.-P. 1998. Cinemagoing Europe. Southern Europe. Dodona Research, Leicester (UK).

Cunningham, J. 2004. Hungarian cinema: from coffee house to multiplex. Wallflower Press, London.

Delon, F. 2000. Les multiplexes. www.culture.fr/culture/actualites/rapports/delon/intro.htm.

Kiss, E., \& Brunella, E. 1995. 100 years of cinema in Hungary - a historical profile. www.mediasalles.it

Klady, L. AMC founder dies of cancer at 78. Durwood was known as an 'innovator' in the exhib world. http://tripatlas.com/Variety_(magazine), 16 July 1999: 40.

Gold, R. 1988. How the power of the circuits could be broken. Screen Finance, 1(1): 16.

Gottsch, H. J. 1995. 100 years of cinema in Austria - a historical profile. www.mediasalles.it.

Gramfors, R., Åhlander, L., \& Borsboom, E. 1995. 100 years of cinema in Sweden - a historical profile. www.mediasalles.it.

Hauersl, T. 2001. Cinemas of Copenhagen. www.in70mm.com/experymints/ cph_cinemas/cph_cinemas.htm

Hayes, G., \& O'Shaughnessy, M. 2005. French cinema. Globalization, representation, and resistance. French Politics Culture \& Society, 23/3: 1-13.

Hellpointer 2004. Aspekte der Entwicklung des Multiplex Kinos in Deutschland. Historie des Multiplex-Kinos in Deutschland. Unpublished working paper, Aachen University.

HDV, Hauptverband Deutscher Filmtheater e. V. 1991. Geschäftsbericht 1990/1991. Wiesbaden.

La Franco, Robert. 1996. Coming soon: a megaplex near you. Forbes, August 12: 133.

L'altracittà, Giornale di periferia. 2009. Multiplex: ecco come sbloccare i lavori, grazie al polo culturale e ai fondi regionali. May 25th

MEDIA Salles. 1992-2003. European Cinema Yearbook. Partly on www.mediasalles.it.

MEDIA Salles. 1994. White Book of the European Exhibition Industry. A report by London Economics and BIPE Conseil. Second edition. www.mediasalles.it/whiteboo/. 
Ministry of Culture of Portugal. 1997. Report of the Inter-Ministerial Commission for the Audiovisual sector. This report has been initially published in Portuguese by the Ministry of Culture of Portugal in June 1997. www.obs.coe.int/oea_publ/eurocine/00001545.html.

Monin, J. 1996. Mobilisation à Montpellier contre l'implantation d'un multiplexe. LeMond.fr, June 13th.

Monzoncillo, J. M. A., \& Villanueva, J. L. (1998): The Film Industry in Spain. Original report commisioned by the European Audiovisual Observatory to Universidad Complutense de Madrid. www.obs.coe.int/oea_publ/eurocine/00001436.html.

Ridder, F. de 1995. 100 Years of Cinema Exhibition in Belgium - A Historical Profile. Published by MEDIA Salles, Media Programme, European Union, www.mediasalles.it.

Rooney, D. 1999. Mega opposition. Italian filmmakers blast studio-lot plex. Variety, Apr. 6.

Rykaer, J. 1995. 100 years of cinema exhibition in Denmark - a historical profile. www.mediasalles.it.

Salvemini, S. 1992. Il cinema italiano: imprenditorialità, efficienza, innovazione. ANEC, Roma.

Schmitt, E. 1992. Zerstörte Strukturen. Film-Dienst, 45: 39.

Screen Digest. 1991. Cinemas in Europe: Circuit Building and Multiplexes. July.

Screen Digest. 1994. UK Multiplex Cinemas: Phase 1 nears maturity. February.

Tagliabue, J. 2000. Now playing Europe: Invasion of the multiplex; with subplots on pride and environment. New York Times, January 27

Trovão, H. 1995. 100 years of cinema exhibition in Portugal - a historical profile. www.mediasalles.it.

Uusitalo, K. 1995. 100 years of cinema exhibition in Finland - a historical profile. www.mediasalles.it.

Vernier, J.-M. 1995. 100 years of cinema exhibition in France - a historical profile. www.mediasalles.it. 
Table 1. Data sources regarding countries not fully covered by Media Salles

\begin{tabular}{|l|l|l|}
\hline \multicolumn{1}{|c|}{ Source } & \multicolumn{1}{|c|}{ Information } & \multicolumn{1}{c|}{ Country } \\
\hline Gottsch (1995) & Some historical data and the first multi-screen & Austria \\
\hline Ridder (1995) & Industry evolution and history & Belgium \\
\hline $\begin{array}{l}\text { Communauté française de Belgique } \\
\text { (1997) }\end{array}$ & Industry structure & Belgium \\
\hline Rykaer (1995) & Historical profile. First multi-screen. & Denmark \\
\hline Hauersl (2001) & History of Palads Teatret & Denmark \\
\hline Uusitalo (1995) & Industry evolution and history & Finland \\
\hline Vernier (1995) & Industry evolution and history & France \\
\hline CNC (2000) & The public of multiplexes & France \\
\hline Delon, F. (2000) & $\begin{array}{l}\text { First numbers of multiplexes; industry evolution and } \\
\text { history; reactions by incumbents; evolution of laws }\end{array}$ & $\begin{array}{l}\text { France and } \\
\text { several others }\end{array}$ \\
\hline Bähr/Neckermann (1997) & Industry structure and evolution & Germany \\
\hline Hellpointer (2004) & Industry structure and evolution & Germany \\
\hline Christie (1995) & Industry evolution and history & Great Britain \\
\hline Couling/Grummit (1998) & First two multiplexes in 1997 & Greece \\
\hline Kiss/Brunella (1995) & Some historical data & Hungary \\
\hline Box Office (2003) & Number of multiplexes and projection & Italy \\
\hline Borsboom (1995) & Industry evolution and history & Netherlands \\
\hline Aas (1995) & Industry evolution and history & Norway \\
\hline Trovão (1995) & Industry evolution and history & Portugal \\
\hline Ministry of Culture of Portugal (1997) & Industry structure and evolution & Portugal \\
\hline MEDIA Salles (1994) & White Book of the European Exhibition Industry & Several \\
\hline Monzoncillo/Villanueva (1998) & Industry structure and evolution & Spain \\
\hline Gramfors/Åhlander/Borsboom (1995) & First multiplex and history & Sweden \\
\hline $\begin{array}{l}\text { Association Cinématographique Suisse } \\
\text { (1995) }\end{array}$ & Industry evolution and history & Switzerland \\
\hline Bipe Conseil (1994) & Major players and founding dates & $\begin{array}{l}\text { UK, Spain and } \\
\text { several others }\end{array}$ \\
\hline
\end{tabular}


Table 2A. Descriptive statistics and correlations for the variables employed for analyses concerning the first adoption of a multiplex cinema

\begin{tabular}{|c|c|c|c|c|c|c|c|c|c|c|}
\hline & & mean & st. dev. & 1 & 2 & 3 & 4 & 5 & 6 & 7 \\
\hline 1 & European Industry Age & 8.68 & 5.85 & 1.00 & & & & & & \\
\hline 2 & Eastern Block & 0.4 & 0.49 & 0.30 & 1.00 & & & & & \\
\hline 3 & GDP per capita & 153.41 & 382.14 & -0.02 & -0.25 & 1.00 & & & & \\
\hline 4 & $\begin{array}{l}\text { European Density }(\log ) \\
\text { Country Standing in the World }\end{array}$ & 2.97 & 2.03 & 0.79 & 0.28 & -0.02 & 1.00 & & & \\
\hline 5 & System & 0.29 & 0.18 & -0.13 & -0.17 & 0.11 & -0.13 & 1.00 & & \\
\hline 6 & Normative distance & 3.8 & 1.03 & 0.25 & 0.14 & -0.14 & 0.23 & -0.33 & 1.00 & \\
\hline 7 & Economic freedom & 9.89 & 6.16 & 0.03 & 0.09 & 0.04 & 0.03 & -0.25 & -0.14 & 1.00 \\
\hline
\end{tabular}

Table 2B. Descriptive statistics and correlations for the variables employed for analyses concerning the founding rates of multiplex cinemas

\begin{tabular}{|c|c|c|c|c|c|c|c|c|c|c|c|c|c|}
\hline & & mean & st. dev. & 1 & 2 & 3 & 4 & 5 & 6 & 7 & 8 & 9 & 10 \\
\hline 1 & Entries & 1.7 & 4.66 & 1.00 & & & & & & & & & \\
\hline 2 & Period $1980-1989$ & 0.38 & 0.49 & -0.27 & 1.00 & & & & & & & & \\
\hline 3 & Period 1990-1999 & 0.39 & 0.49 & 0.07 & -0.60 & 1.00 & & & & & & & \\
\hline 4 & GDP per capita & 311.24 & 448.55 & 0.09 & -0.04 & 0.01 & 1.00 & & & & & & \\
\hline & Country Standing in the World & & & & & & & & & & & & \\
\hline 5 & System & 0.35 & 0.19 & 0.35 & -0.01 & 0.00 & -0.01 & 1.00 & & & & & \\
\hline 6 & European Density $(\log )$ & 4.00 & 2.27 & 0.31 & -0.88 & 0.30 & 0.16 & -0.01 & 1.00 & & & & \\
\hline 7 & National density & 12.32 & 32.58 & 0.70 & -0.29 & -0.10 & 0.05 & 0.40 & 0.36 & 1.00 & & & \\
\hline 8 & Normative Distance & 3.50 & 1.35 & -0.24 & 0.00 & 0.01 & -0.12 & -0.40 & 0.01 & -0.29 & 1.00 & & \\
\hline 9 & Economic Freedom & 11.45 & 6.08 & -0.19 & 0.01 & 0.00 & 0.16 & -0.32 & 0.00 & -0.19 & -0.05 & 1.00 & \\
\hline 10 & Number of monoscreens $(\log )$ & 2.49 & 0.52 & 0.18 & 0.13 & -0.01 & -0.27 & 0.42 & -0.16 & 0.11 & 0.02 & -0.58 & 1.00 \\
\hline
\end{tabular}


Table 3. Event history models to predict the first adoption of the multiplex form across various countries, $1980-2001$

\begin{tabular}{|c|c|c|c|c|c|}
\hline Variables & Model 1 & Model 2 & Model 3 & $\begin{array}{l}\text { Only countries } \\
\text { with full } \\
\text { information on } \\
\text { regulative } \\
\text { distance }\end{array}$ & $\begin{array}{l}\text { No control for } \\
\text { standing in the } \\
\text { world system }\end{array}$ \\
\hline $\begin{array}{l}\text { European Industry } \\
\text { Tenure 01-06 }\end{array}$ & $\begin{array}{c}-5.20^{* *} \\
(.90)\end{array}$ & $\begin{array}{c}-3.30 * * \\
(.81)\end{array}$ & $\begin{array}{c}-3.30^{* *} \\
(.80)\end{array}$ & $\begin{array}{c}-3.30 * * \\
(.91)\end{array}$ & $\begin{array}{c}-2.54^{* *} \\
(.71)\end{array}$ \\
\hline $\begin{array}{l}\text { European Industry } \\
\text { Tenure 07-15 }\end{array}$ & $\begin{array}{c}-7.10^{* *} \\
(1.52)\end{array}$ & $\begin{array}{c}-5.29 * * \\
(1.66)\end{array}$ & $\begin{array}{c}-5.24 * * \\
(1.65)\end{array}$ & $\begin{array}{c}-5.76 * * \\
(1.77)\end{array}$ & $\begin{array}{c}-4.16 * * \\
(1.45)\end{array}$ \\
\hline $\begin{array}{l}\text { European Industry } \\
\text { Tenure 15-more }\end{array}$ & $\begin{array}{l}-6.78^{* *} \\
(2.14)\end{array}$ & $\begin{array}{c}-4.53 * * \\
(2.32)\end{array}$ & $\begin{array}{c}-4.47 * * \\
(2.34)\end{array}$ & $\begin{array}{c}-4.73 * * \\
(2.49)\end{array}$ & $\begin{array}{c}-3.52 * * \\
(2.18)\end{array}$ \\
\hline Eastern Block & $\begin{array}{c}-1.32^{* *} \\
(.62)\end{array}$ & $\begin{array}{c}-1.49 * * \\
(.64)\end{array}$ & $\begin{array}{c}-1.50 * * \\
(.72)\end{array}$ & $\begin{array}{l}-1.03 \\
(.65)\end{array}$ & $\begin{array}{c}-1.63 * * \\
(.64)\end{array}$ \\
\hline GDP per capita & $\begin{array}{c}.00063 \\
(.00079)\end{array}$ & $\begin{array}{c}.00048 \\
(.00070)\end{array}$ & $\begin{array}{c}.00046 \\
(.00070)\end{array}$ & $\begin{array}{c}.00014 \\
(.00049)\end{array}$ & $\begin{array}{c}.00015 \\
(.00059)\end{array}$ \\
\hline $\begin{array}{l}\text { Country Standing in the } \\
\text { World System }\end{array}$ & $\begin{array}{c}1.98^{* *} \\
(.91)\end{array}$ & $\begin{array}{l}1.03 \\
(.74)\end{array}$ & $\begin{array}{l}1.17 \\
(.79)\end{array}$ & $\begin{array}{l}1.34^{*} \\
(.78)\end{array}$ & -- \\
\hline European density (log) & $\begin{array}{l}.89 * * \\
(.35)\end{array}$ & $\begin{array}{c}1.01^{* *} \\
(.39)\end{array}$ & $\begin{array}{l}.99 * * \\
(.38)\end{array}$ & $\begin{array}{c}1.16^{* *} \\
(.41)\end{array}$ & $\begin{array}{l}.86 * * \\
(.33)\end{array}$ \\
\hline Economic Freedom & & & $\begin{array}{l}.0093 \\
(.033)\end{array}$ & $\begin{array}{l}.051 * \\
(.029)\end{array}$ & $\begin{array}{l}.010 \\
(.032)\end{array}$ \\
\hline Normative distance & & $\begin{array}{l}-.58^{* *} \\
(.18)\end{array}$ & $\begin{array}{l}-.56 * * \\
(.18)\end{array}$ & $\begin{array}{c}-.47 * * \\
(.16)\end{array}$ & $\begin{array}{c}-.59 * * \\
(.20)\end{array}$ \\
\hline Number of observations & 339 & 339 & 316 & 241 & 365 \\
\hline Number of countries & 24 & 24 & 24 & 19 & 29 \\
\hline $\begin{array}{c}-2 * \log \text { Likelihood } \\
\text { (1 d.f. with nested model) }\end{array}$ & $6.08 * *$ & $6.66^{* *}$ & 0.32 & $1.7^{*}$ & 0.38 \\
\hline
\end{tabular}


Table 4. GEE negative binomial models for the founding rates of multiplex cinemas across various countries, $1980-2005$

\begin{tabular}{|c|c|c|c|c|}
\hline Variables & Model 1 & Model 2 & Model 3 & Model 4 \\
\hline Constant & $\begin{array}{l}-4.611^{* *} \\
(1.26)\end{array}$ & $\begin{array}{c}-1.81 * * \\
(.62)\end{array}$ & $\begin{array}{l}-2.69 * * \\
(.82)\end{array}$ & $\begin{array}{c}-2.51 * * \\
(.68)\end{array}$ \\
\hline Period 1980-1989 & $\begin{array}{l}-.63 \\
(.52)\end{array}$ & $\begin{array}{l}-.66 \\
(.61)\end{array}$ & $\begin{array}{l}-.67 \\
(.75)\end{array}$ & $\begin{array}{l}.80 \\
(.73)\end{array}$ \\
\hline Period 1990-1999 & $\begin{array}{c}.45 \\
(.32) \\
.0000 * \\
(.0003)\end{array}$ & $\begin{array}{l}.36^{*} \\
(.21) \\
.0000^{*} \\
(.0002)\end{array}$ & $\begin{array}{c}.47 * \\
(.28) \\
.0004 * \\
(.0002)\end{array}$ & $\begin{array}{c}.37 \\
(.27) \\
.0005 * \\
(.0002)\end{array}$ \\
\hline Number of monoscreen cinemas $(\log )$ & $\begin{array}{l}1.04 * \\
(.48)\end{array}$ & $\begin{array}{l}.94^{*} \\
.(32)\end{array}$ & $\begin{array}{l}.31 \\
. .25)\end{array}$ & $\begin{array}{l}.48^{*} \\
(.26)\end{array}$ \\
\hline Country Standing in the World System & $\begin{array}{l}1.02 * * \\
(.91)\end{array}$ & $\begin{array}{l}-.33 \\
-.89)\end{array}$ & $\begin{array}{l}.076 \\
(.69)\end{array}$ & $\begin{array}{l}.29 * \\
(.70)\end{array}$ \\
\hline European Density (log) & $\begin{array}{l}.62 * * \\
(.17)\end{array}$ & $\begin{array}{l}.31 * * \\
(.15)\end{array}$ & $\begin{array}{l}.28^{*} \\
(.15)\end{array}$ & $\begin{array}{l}.33 * * \\
(.15)\end{array}$ \\
\hline National density & $\begin{array}{l}.010 * * \\
(.003)\end{array}$ & $\begin{array}{l}.091 * * \\
(.011)\end{array}$ & (.115** & $\begin{array}{l}.087 * * \\
(.016)\end{array}$ \\
\hline National density2 & & $\begin{array}{c}-.00084 * * \\
(.0002)\end{array}$ & $\begin{array}{c}-.0011 * * * \\
(.00021)\end{array}$ & $\begin{array}{c}-.00078^{* *} \\
(.00020)\end{array}$ \\
\hline National density 3 & & $\begin{array}{l}.00000022^{* *} \\
(.00000082)\end{array}$ & $\begin{array}{l}.00000032 * * \\
(.00000075)\end{array}$ & $\begin{array}{l}.00000020 * * \\
(.000000065)\end{array}$ \\
\hline Normative Distance & $\begin{array}{c}-.33 * * \\
(.15) \\
(.15)\end{array}$ & $\begin{array}{l}-.16 * * \\
(.080)\end{array}$ & $\begin{array}{c}-.16 * * \\
(.08)\end{array}$ & $\begin{array}{l}-.17 * * \\
(.090)\end{array}$ \\
\hline Economic Freedom & $\begin{array}{r}-.026 \\
(.022)\end{array}$ & $\begin{array}{r}-.013 \\
(.016)\end{array}$ & $\begin{array}{l}-.021 \\
(.019)\end{array}$ & $\begin{array}{l}-.017 \\
(.020)\end{array}$ \\
\hline Density*Normative Distance & & & $\begin{array}{l}.029 * * \\
(.011)\end{array}$ & \\
\hline Density2*Normative Distance & & & $\begin{array}{c}-.00037 * * \\
(.00015)\end{array}$ & \\
\hline Density $3 *$ Normative Distance & & & $\begin{array}{l}.00000122 * * * \\
(.00000005)\end{array}$ & \\
\hline Density 1* Economic Freedom & & & & $\begin{array}{l}-.00059 \\
(.0023)\end{array}$ \\
\hline Density2* Economic Freedom & & & & $\begin{array}{c}.000012 \\
(.000034)\end{array}$ \\
\hline Density $3 *$ Economic Freedom & & & & $\begin{array}{c}-.0000000039 \\
(.00000012)\end{array}$ \\
\hline Number of observations & 487 & 487 & 487 & 487 \\
\hline QIC & 1316.63 & 1200.47 & 1197.57 & 1200.40 \\
\hline
\end{tabular}

$* \mathrm{p}<.10 ; * * \frac{\mathrm{p}<.05 ; \text { Standard errors in parentheses }}{4}$ 
Figure 1. Density of the multiplex population as cumulative number of entries and annual number of new multiplexes per year in 29 European countries

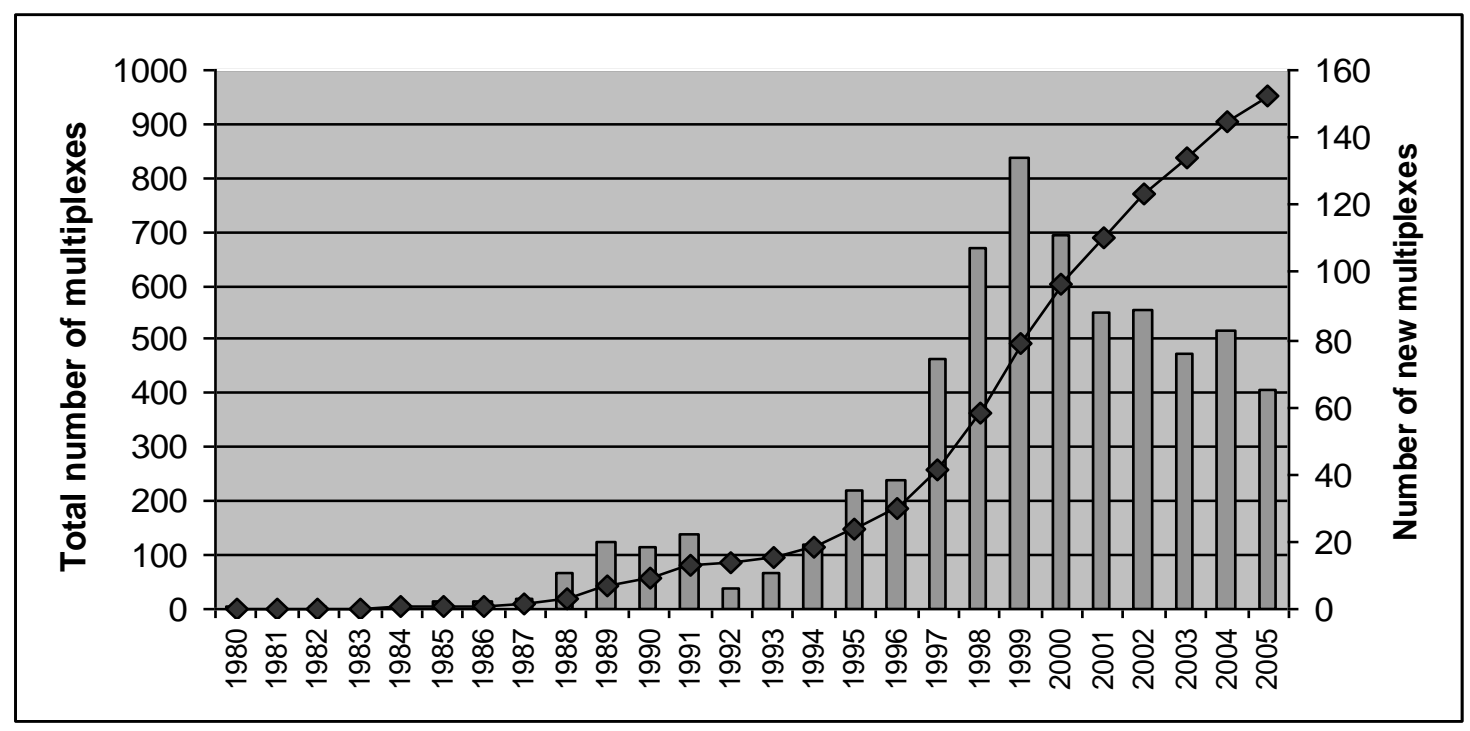


Figure 2. Annual founding activities in the multiplex population in 6 countries
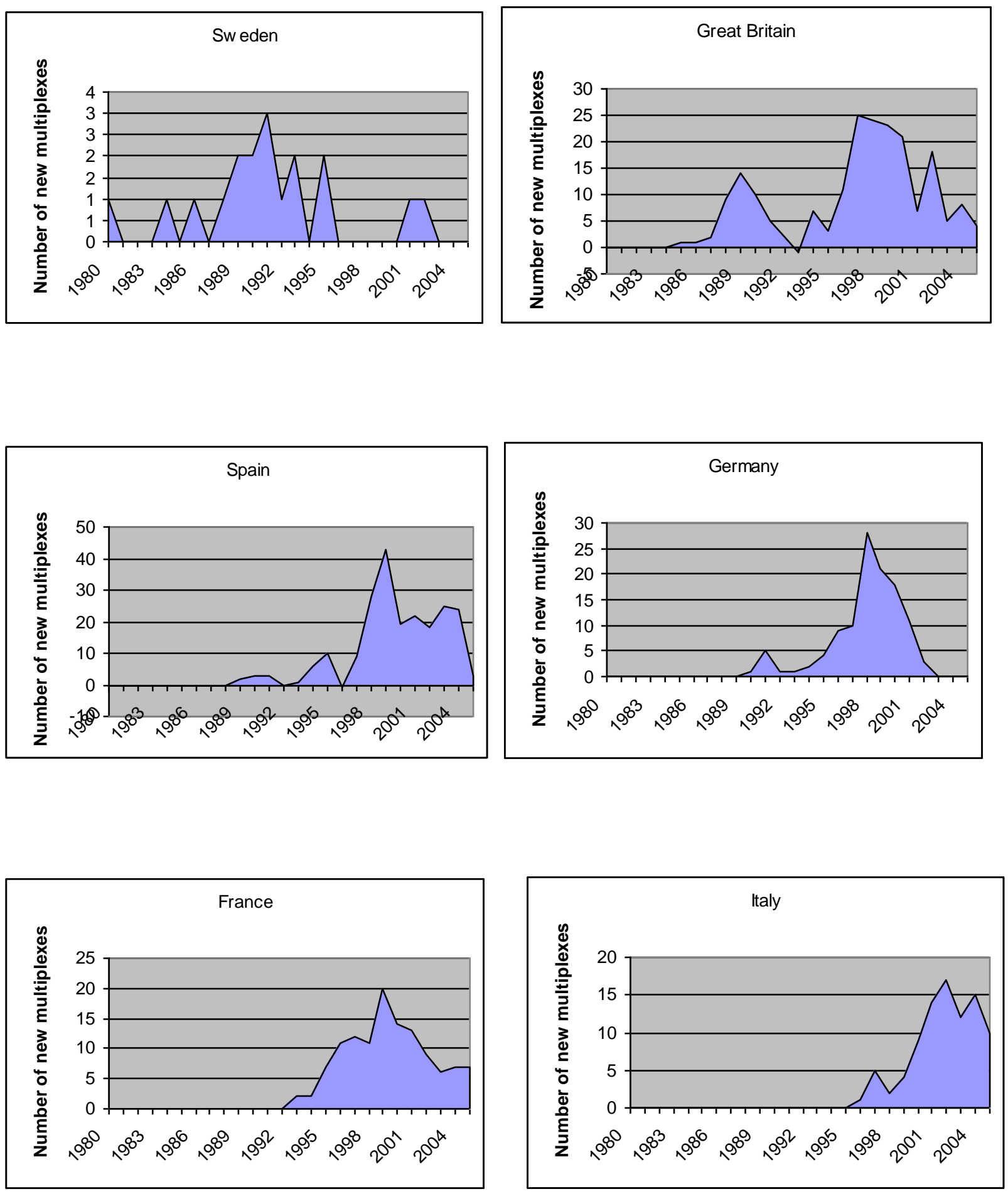
Figure 3. The impact of national density of multiplex cinemas on founding rates across various European Countries, 1980-2005

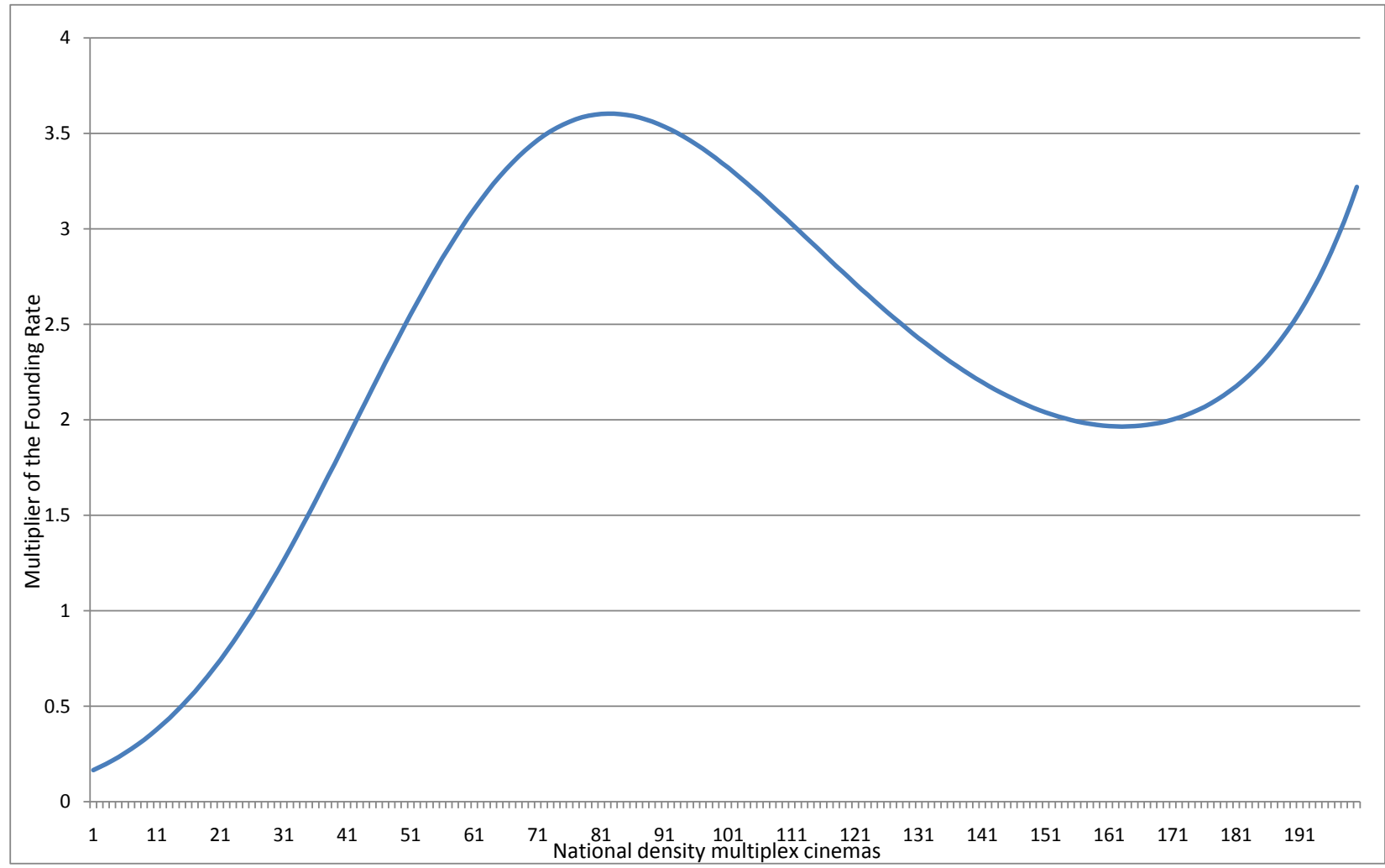

Figure 4. The impact of national density on the founding rates of multiplex cinemas at different values of normative distance

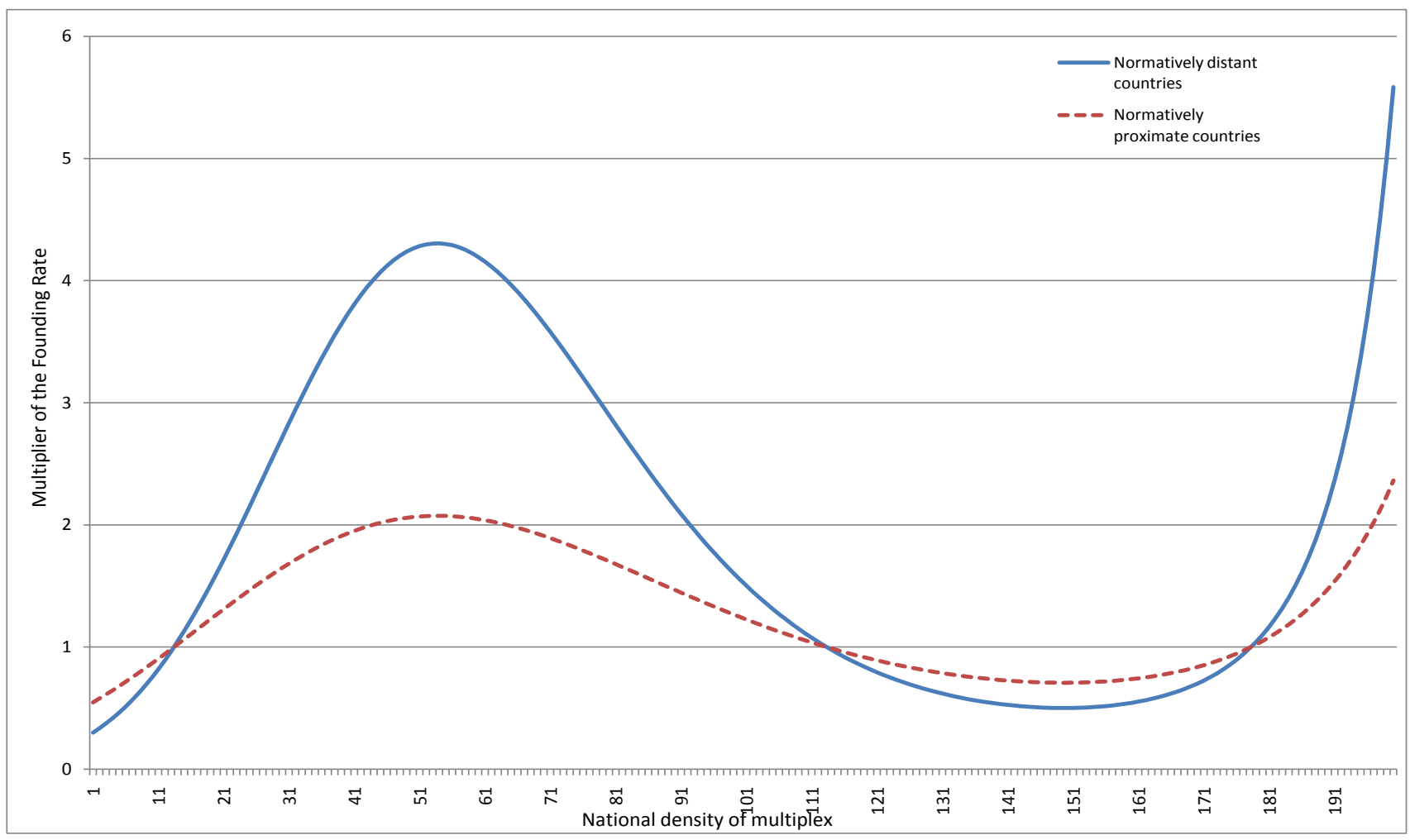


Figure 5. Institutional and economic mechanisms behind adoption and founding rates of a globally legitimated organizational form

\begin{tabular}{|c|c|c|c|c|}
\hline Legitimation Phases & Pre-ENTRY & EARLY DIFFUSION & FIRST SLOW DOWN & LEGITIMATION \\
\hline \multicolumn{5}{|c|}{ EARLY ENTRANTS: CULTURALLY “CLOSER” COUNTRIES } \\
\hline 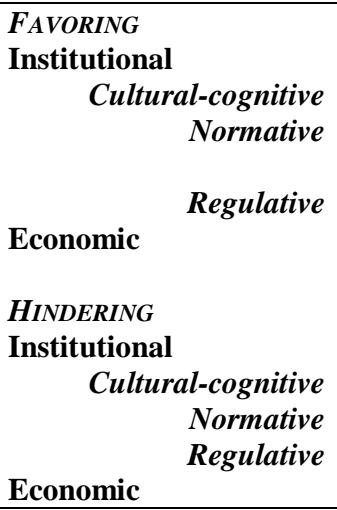 & $\begin{array}{c}\text { Theorization } \\
\text { Diffusion of templates } \\
\text { n.r. } \\
\text { Information cascades } \\
\text { Learning }\end{array}$ & $\begin{array}{c}\text { Cultural fit } \\
\text { Emulation } \\
\text { Regulative matching } \\
\text { Seizing of opportunities } \\
\\
\text { Categorical imperative } \\
\text { n.r. } \\
\text { n.r. } \\
\text { Existing market structures }\end{array}$ & $\begin{array}{c}\text { Robust design } \\
\text { Trait-based imitation } \\
\text { Proselytizing } \\
\text { n.r. } \\
\text { Aggressive marketing } \\
\end{array}$ & $\begin{array}{l}\text { Form becomes ordinary } \\
\text { n.r. } \\
\text { n.r. } \\
\text { n.r. } \\
\text { Economic efficiency }\end{array}$ \\
\hline
\end{tabular}

LATE ENTRANTS: CULTURALLY “MORE DISTANT” COUNTRIES

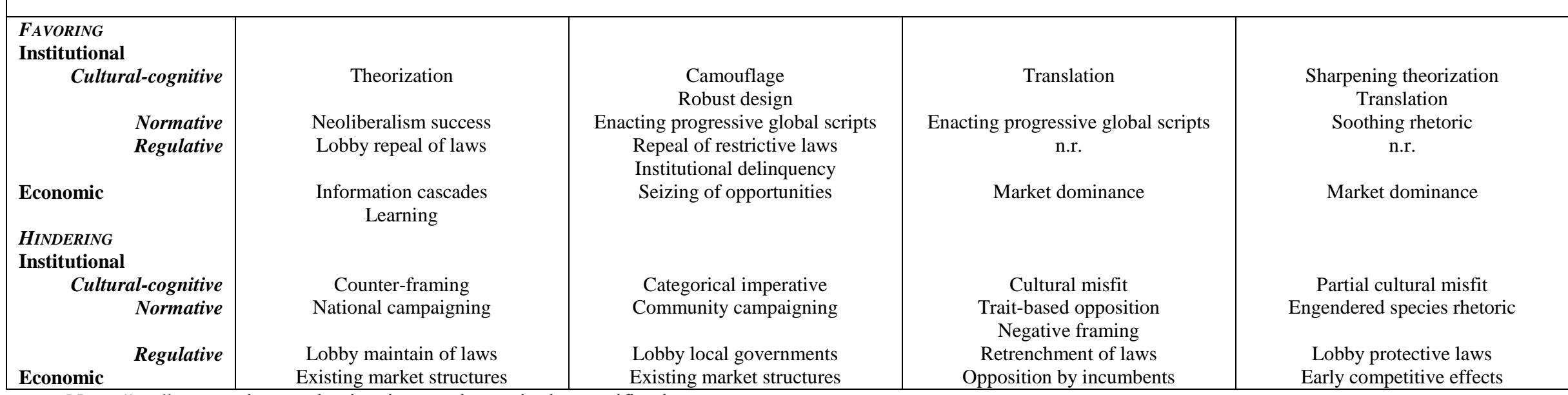

Note: "n.r." means that mechanism is not relevant in the specific phase 
Appendix. GEE negative binomial models for the founding rates of multiplex cinemas across various countries, 1980-2005. Alternative moderators.

\begin{tabular}{|c|c|c|c|}
\hline Variables & $\begin{array}{l}\text { Moderator: year of entry of } \\
\text { multiplex form }\end{array}$ & $\begin{array}{l}\text { Moderator: year of entry of first } \\
\text { McDonald's fast food restaurant }\end{array}$ & $\begin{array}{l}\text { Moderator: local market share of } \\
\text { US-produced movies }\end{array}$ \\
\hline Constant & $\begin{array}{l}-2.28 * * \\
(.43)\end{array}$ & $\begin{array}{l}-2.15^{* *} \\
(.60)\end{array}$ & $\begin{array}{c}-2.91 * * \\
(1.01)\end{array}$ \\
\hline Period 1980-1989 & $\begin{array}{l}-.71 \\
(.59)\end{array}$ & $\begin{array}{l}-.61 \\
(.76)\end{array}$ & $\begin{array}{l}-.61 \\
(.90)\end{array}$ \\
\hline Period 1990-1999 & $\begin{array}{l}.66 * * \\
(.20)\end{array}$ & $\begin{array}{l}.66 * * \\
(.29)\end{array}$ & $\begin{array}{l}.24 \\
(.34)\end{array}$ \\
\hline GDP per capita & $\begin{array}{l}.0004 * \\
(.0002)\end{array}$ & $\begin{array}{l}.0004 * * \\
(.0002)\end{array}$ & $\begin{array}{l}.0004 \\
(.0003)\end{array}$ \\
\hline Number of monoscreen cinemas $(\log )$ & $\begin{array}{l}.41^{*} \\
(.25)\end{array}$ & $\begin{array}{l}.27 \\
(.20)\end{array}$ & $\begin{array}{l}.78 * * \\
(.37)\end{array}$ \\
\hline Country Standing in the World System & $\begin{array}{l}.67 \\
(.56)\end{array}$ & $\begin{array}{c}1.20 * * \\
(.68)\end{array}$ & $\begin{array}{l}.79 \\
(.89)\end{array}$ \\
\hline European Density (log) & $\begin{array}{l}.32 * * \\
(.11)\end{array}$ & $\begin{array}{l}.29 * \\
(.15)\end{array}$ & $\begin{array}{l}.22 \\
(.18)\end{array}$ \\
\hline National density & $\begin{array}{l}.134 * * \\
(.011)\end{array}$ & $\begin{array}{l}.12 * * \\
(.014)\end{array}$ & $\begin{array}{l}.084 * * \\
(.015)\end{array}$ \\
\hline National density 2 & $\begin{array}{l}-.0016 * * \\
(.0002)\end{array}$ & $\begin{array}{l}-.0010 * * \\
(.00020)\end{array}$ & $\begin{array}{c}-.00076 * * \\
(.00018)\end{array}$ \\
\hline National density3 & $\begin{array}{l}.0000053^{* *} \\
(.00000058)\end{array}$ & $\begin{array}{l}.0000028 * * \\
(.00000070)\end{array}$ & $\begin{array}{l}.0000020^{* *} \\
(.0000062)\end{array}$ \\
\hline Moderator & $\begin{array}{l}-.056 * * \\
(.024)\end{array}$ & $\begin{array}{l}.0019 \\
(.015)\end{array}$ & $\begin{array}{l}.015 \\
(.014)\end{array}$ \\
\hline Density*Moderator & $\begin{array}{l}.018 * * \\
(.0024)\end{array}$ & $\begin{array}{l}.0052^{* *} \\
(.0017)\end{array}$ & $\begin{array}{l}-.0029 * * \\
(.0011)\end{array}$ \\
\hline Density $2 *$ Moderator & $\begin{array}{l}-.00029 * * \\
(.00004)\end{array}$ & $\begin{array}{l}-.000050^{*} \\
(.000028)\end{array}$ & $\begin{array}{l}.000048 * * \\
(.000017)\end{array}$ \\
\hline Density $3 *$ Moderator & $\begin{array}{l}.00000105 * * \\
(.00000013) \\
\end{array}$ & $\begin{array}{r}.00000015 \\
.00000010)\end{array}$ & $\begin{array}{l}-.00000018^{* *} \\
(.000000065)\end{array}$ \\
\hline Number of observations & 487 & 487 & 248 \\
\hline QIC & 1176.48 & 1181.93 & 883.93 \\
\hline
\end{tabular}

$* \mathrm{p}<.10 ; * * \mathrm{p}<.05 ;$ Standard errors in parentheses 